\title{
Pd-Catalyzed Heck Reactions of Aryl Bromides with 1,2-Diarylethenes
}

\author{
Jones Limberger, Silvia Poersch and Adriano L. Monteiro* \\ Laboratory of Molecular Catalysis, Instituto de Química, Universidade Federal do Rio Grande do Sul (UFRGS), \\ Av. Bento Gonçalves, 9500, CP 15003, 91501-970 Porto Alegre-RS, Brazil
}

\begin{abstract}
Um sistema catalítico composto por $\mathrm{Pd}(\mathrm{OAc})_{2}$ e $\mathrm{P}(o \text {-tol })_{3}$ foi aplicado na reação de Heck entre brometos de arila e diariletenos. Utilizando-se $\mathrm{K}_{2} \mathrm{CO}_{3}$ como base e DMF como solvente, olefinas triarilsubstituídas foram obtidas com rendimentos de bons a excelentes. Brometos de arila com substituintes eletroretiradores foram menos ativos para a reação de acoplamento Heck e levaram à formação de produto de homoacoplamento em quantidades substanciais, indicando que a adição oxidativa não deve ser a etapa lenta da reação. A presença de substituintes no diarileteno afetou drasticamente a seletividade da reação. Realizou-se também a dupla arilação do estireno, levando diretamente à olefina triarilsubstituída, com rendimento de $73 \%$.
\end{abstract}

A catalytic system composed of $\mathrm{Pd}(\mathrm{OAc})_{2}$ and $\mathrm{P}(\mathrm{o} \text {-tol })_{3}$ was found to be effective for the Heck reaction of aryl bromides with diarylethylenes. Using $\mathrm{K}_{2} \mathrm{CO}_{3}$ as a base and DMF as a solvent, trisubstituted olefins were obtained in good to excellent yields. Aryl bromides containing an electron-withdrawing group in para position were less reactive for the Heck coupling reaction and gave substantial amount of homocoupling by-product suggesting that oxidative addition is not the rate-determining step. Electron withdrawing group substituent in the para position of stilbene affects the regioselectivity of the reaction. In this case, the phenyl group from the $\mathrm{Ph}-\mathrm{Pd}$ complex migrates preferentially to the same carbon of the double bond to which the phenyl is bonded. Finally, a one pot sequential double Heck arylation of styrene was performed, giving trisubstituted olefin with an overall yield of $73 \%$.

Keywords: Heck reaction, palladium, trisubstituted olefins, double arylation

\section{Introduction}

Palladium-catalyzed Heck cross-coupling reactions are one of the most efficient methods for the construction of $\mathrm{C}-\mathrm{C}$ bonds and have found widespread use in organic synthesis. ${ }^{1}$ Most Heck reactions involves arylation of monosubstituted alkenes (especially acrylates and styrene derivatives) to allow synthesis of disubstituted olefins with regio and stereoselective control. In contrast, fewer studies have been conducted on the arylation of disubstituted olefins or double arylation of mono-substituted olefins, to yield trisubstituted products. Stereocontrol during the synthesis of highly substituted double bonds is a significant challenge in organic synthesis, ${ }^{2}$ and the Heck reaction remains an important alternative. In this context, some examples of regio and stereoselective syntheses of trisubstituted $\alpha, \beta$-unsaturated compounds, such as nitriles, ${ }^{3,4}$ cinnamates ${ }^{5-10}$ and aldehydes,${ }^{11}$ through either monoarylation of disubstituted olefins or direct diarylation of monosubstituted olefins, have been reported. Arylation of disubstituted alkenes without an electron-withdrawing group conjugated to the $\mathrm{C}=\mathrm{C}$ double bond (e.g., $\alpha$ - or $\beta$-methylstyrene, ${ }^{10,12}$ 1,1-diphenylethene and transstilbene $)^{13-15}$ has also been investigated. However, to the best of our knowledge, no example using substituted stilbenes has been described. Recently, we reported the Heck arylation of trans-stilbene using $\mathrm{Pd}(\mathrm{OAc})_{2} / \mathrm{P}(o \text {-tol })_{3}$ and $\mathrm{K}_{2} \mathrm{CO}_{3}$ as a base. ${ }^{16}$ Using this methodology, we were able to obtain a triarylolefin intermediate for tamoxifen synthesis at $98 \%$ of yield with $87 \%$ of stereoselectivity for the $Z$ isomer. Here we describe the Heck reaction of trans-stilbene derivatives and 1,1-diphenylethene with aryl halides in order to obtain substituted triarylethenes. We also report our findings concerning the influence of halide or olefin electro-donating and withdrawing groups on activity, regio and stereoselectivity.

*e-mail: adriano.monteiro@ufrgs.br 


\section{Experimental}

\section{Procedure for Heck reaction coupling of stilbenes and aryl bromides}

An oven-dried resealable Schlenk flask was charged with trans-stilbene $(0.5 \mathrm{mmol}), \mathrm{Pd}(\mathrm{OAc})_{2}(2.2 \mathrm{mg}$, $0.01 \mathrm{mmol}), \mathrm{P}(\mathrm{o}-\mathrm{tol})_{3}(6.1 \mathrm{mg}, 0.02 \mathrm{mmol})$, evacuated and black-filled with argon. Then, DMF $(3 \mathrm{~mL})$, aryl bromide $(0.75 \mathrm{mmol})$ and $\mathrm{K}_{2} \mathrm{CO}_{3}(138 \mathrm{mg}, 1.0 \mathrm{mmol})$ were added. The reaction mixture was stirred at $130{ }^{\circ} \mathrm{C}$ for the desired time. Conversion, regio and diasteroselectivity were determined by the techniques: gas chromatography (GC), gas chromatography-mass spectrometry (GC-MS) and ${ }^{1} \mathrm{H}$ and ${ }^{13} \mathrm{C}$ nuclear magnetic resonance (NMR). Coupling products were compared with authentic standards obtained from Suzuki coupling of $E$-bromostylbenes with aryl boronic acids (triphenylethene and 1-aryl-1,2diphenylethenes) ${ }^{17}$ or from Heck coupling of aryl bromides with 1,1-diphenylethene (1-aryl-2,2-diphenylethenes). The GC yields were obtained using $0.5 \mathrm{mmol}$ of olefin while the isolated yields were obtained using higher scale (1.5 mmol of olefin).

\section{Procedure for competitive Heck reaction coupling of trans- stilbene and aryl halides}

An oven-dried resealable Schlenk flask was charged with trans-stilbene $(0.5 \mathrm{mmol}), \mathrm{Pd}(\mathrm{OAc})_{2}(2.2 \mathrm{mg}$, $0.01 \mathrm{mmol})$ and $\mathrm{P}(o-\mathrm{tol})_{3}(6.1 \mathrm{mg}, 0.02 \mathrm{mmol})$, evacuated and black-filled with argon. Then, DMF ( $3 \mathrm{~mL})$, two aryl halides (0.25 mmol each) and $\mathrm{K}_{2} \mathrm{CO}_{3}(138 \mathrm{mg}, 1.0 \mathrm{mmol})$ were added. The reaction mixture was stirred at $130{ }^{\circ} \mathrm{C}$ for $5 \mathrm{~h}$ and conversion, regio and diasteroselectivity were determined by GC and GC-MS analysis.

Procedure for competitive Heck reaction coupling of transstilbene, 1-nitro-4-styrylbenzene and 1-(4-methoxystyryl) benzene with bromobenzene

An oven-dried resealable Schlenk flask was charged with two olefins $(0.25 \mathrm{mmol}+0.25 \mathrm{mmol}), \mathrm{Pd}(\mathrm{OAc})_{2}$ $(2.2 \mathrm{mg}, 0.01 \mathrm{mmol})$, and $\mathrm{P}(o \text {-tol })_{3}(6.1 \mathrm{mg}, 0.02 \mathrm{mmol})$, evacuated and black-filled with argon. Then, $\operatorname{DMF}(3 \mathrm{~mL})$, bromobenzene $(0.5 \mathrm{mmol}, 78 \mathrm{mg})$ and $\mathrm{K}_{2} \mathrm{CO}_{3}(138 \mathrm{mg}$, $1.0 \mathrm{mmol}$ ) were added. The reaction mixture was stirred at $130^{\circ} \mathrm{C}$ for $5 \mathrm{~h}$ and conversion, regio- and diasteroselectivity were determined by GC and GC-MS analysis.

\section{Procedure for competitive Heck reaction coupling of trans-} stilbene and 1,1-diphenylethene with bromoanisole

An oven-dried resealable Schlenk flask was charged with trans-stilbene $(0.25 \mathrm{mmol}, 45 \mathrm{mg}), 1,1$-diphenylethene (0.25 mmol, $45 \mathrm{mg}), \mathrm{Pd}(\mathrm{OAc})_{2}(2.2 \mathrm{mg}, 0.01 \mathrm{mmol})$, and
$\mathrm{P}(o-\text { tol })_{3}(6.1 \mathrm{mg}, 0.02 \mathrm{mmol})$, evacuated and black-filled with argon. Then, DMF ( $3 \mathrm{~mL})$, bromoanisole $(0.5 \mathrm{mmol}$, $94 \mathrm{mg})$ and $\mathrm{K}_{2} \mathrm{CO}_{3}(138 \mathrm{mg}, 1.0 \mathrm{mmol})$ were added. The reaction mixture was stirred at $130{ }^{\circ} \mathrm{C}$ for $5 \mathrm{~h}$ and conversion, regio- and diasteroselectivity were determined by GC and GC-MS analysis.

\section{Results and Discussion}

Recently, we reported the Heck arylation of transstilbene to obtain a tamoxifen intermediate. ${ }^{16}$ In that report, the catalyst system was composed of $\mathrm{Pd}(\mathrm{OAc})_{2}$ and $\mathrm{P}(o \text {-tol })_{3}$. Classical bases for the Heck reaction, such as $\mathrm{Et}_{3} \mathrm{~N}$ or $\mathrm{NaOAc}$, gave only moderate yields and selectivities, and the best results were obtained using $\mathrm{K}_{2} \mathrm{CO}_{3}$ as a base. Due to high steric demands, coupling of trans-stilbene with aryl bromides required higher temperature $\left(130{ }^{\circ} \mathrm{C}\right)$ and reaction time $(48 \mathrm{~h})$ than those necessary for coupling with styrene. Using these optimized conditions, triphenylethene was obtained at $89 \%$ yield from coupling phenyl bromide and trans-stilbene (Table 1, entry 1).

Coupling of 4-bromoanisole with trans-stilbene resulted in 1,2-diphenyl-1-(4-metoxyphenyl)ethene at $79 \%$ yield with an E: $Z$ ratio of 83:17 (Table 1, entry 2). This stereoselectivity is higher than previously reported for the arylation of trans-stilbene with 4-bromoanisole in the presence of $0.2 \%$ catalyst $\left[\mathrm{Pd}\left(\mathrm{C}_{3} \mathrm{H}_{5}\right) \mathrm{Cl}\right]_{2}$ and cis,cis,cis-1,2,3,4-tetrakis(diphenylphosphanylmethyl)cyclopentane (Tedicyp) as the phosphine ligand (75\% yield and $E: Z=61: 39) .{ }^{13}$ It is important to point out that in the presence of phosphine-free nanoparticles, coupling of phenyl chloride with trans-stilbene gave only the $E$-isomer. ${ }^{18}$ Depending on the experimental conditions, the Heck reaction is believed to use a neutral or cationic (or polar) mechanism. ${ }^{19,20}$ In Scheme 1, a simplified catalytic cycle for the Heck reaction is shown, based on the neutral mechanism proposed by Heck with $\mathrm{Pd}(\mathrm{OAc})_{2}$ associated with monophosphine ligands as the precursor, ${ }^{21,22}$ and adapted by us for the particular case of trans-stilbene derivatives as alkenes. As shown in Scheme 1, stereoselecitvity of the Heck reaction is defined by syn-elimination. In the case of coupling 4-bromoanisol with trans-stilbene $\left(\mathrm{Ar}=4-\mathrm{MeOC}_{6} \mathrm{H}_{4}\right.$ and $\mathrm{Ar}_{1}=\mathrm{Ph}$ in Scheme 1), syn-elimination leads to a trisubstituted alkene with both phenyl groups of the stilbene derivative on the same side, even though only the $E$ steroisomer is expected. The presence of the $Z$ isomer can be explained by a $\mathrm{Pd}-\mathrm{H}$ catalyzed isomerization process that may be due to (i) isomerization of the starting alkene; (ii) postreaction isomerization of the trisubstituted alkene product; (iii) isomerization of the coordinated alkene to the $\mathrm{Pd}-\mathrm{H}$ 
Table 1. Pd-catalyzed Heck reaction of trans-stilbene derivatives with aryl bromides ${ }^{\mathrm{a}}$

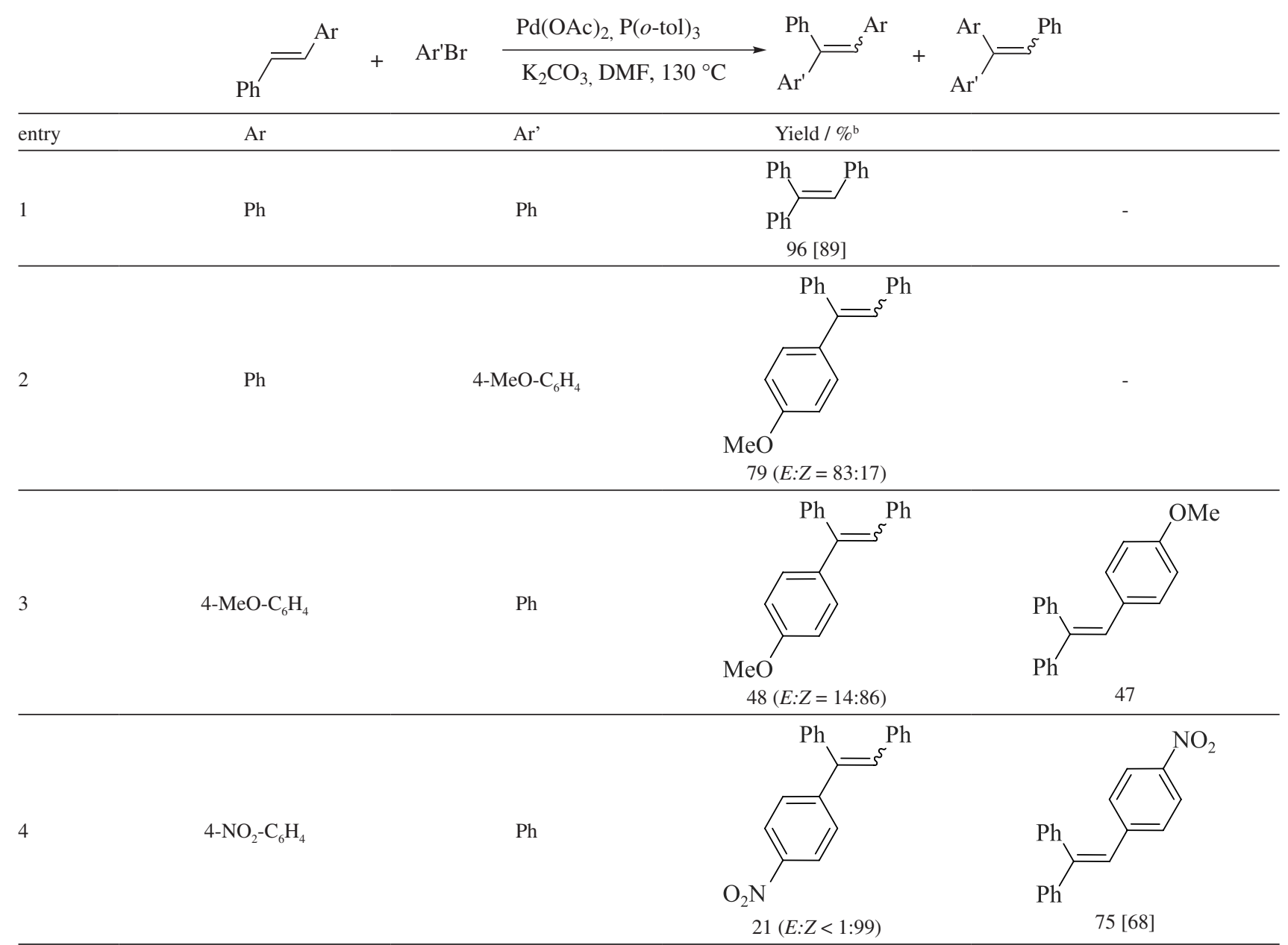

a Reaction conditions for $\mathrm{GC}$ analysis: stilbene $(0.5 \mathrm{mmol})$, aryl bromide $(0.75 \mathrm{mmol}), \mathrm{K}_{2} \mathrm{CO}_{3}(1 \mathrm{mmol}), \mathrm{Pd}(\mathrm{OAc})_{2}(2 \mathrm{~mol} \%), \mathrm{P}(o \text {-tol })_{3}(4 \mathrm{~mol} \%), \mathrm{DMF}$ $(3 \mathrm{~mL}), 130{ }^{\circ} \mathrm{C}, 48 \mathrm{~h}$; reaction conditions for isolated yields: stilbene $(1.5 \mathrm{mmol})$, aryl bromide $(2.25 \mathrm{mmol}), \mathrm{K}_{2} \mathrm{CO}_{3}(3 \mathrm{mmol}), \mathrm{Pd}(\mathrm{OAc})_{2}(2 \mathrm{~mol} \%)$, $\mathrm{P}(o \text {-tol })_{3}(4 \mathrm{~mol} \%)$, DMF $(9 \mathrm{~mL}), 130^{\circ} \mathrm{C}, 48 \mathrm{~h}$; byields refer to GC yields (with undecane as an internal standard) and values in square brackets refer to yields of isolated products.

complex before alkene dissociation. Regardless of the isomerization process, an approximately equal mixture of $E$ and $Z$ isomers is expected if the isomerization reaction is under thermodynamic control.

Next, the coupling of bromobenzene with substituted trans-stilbenes was examined (Table 1, entries 3 and 4). When an aryl group different than phenyl is used for coupling with trans-stilbene $\left(\mathrm{Ar}_{1} \neq \mathrm{Ph}\right.$ in Scheme 1), two syn insertion approaches are possible, and, thus, two regioisomers can be formed. No significant effects on regioselectivity in terms of steric effects are expected for substituents at the para position. Therefore, assuming the same mechanism for both alkenes, the regioisomer distribution basically depends on the electronic effects of the group present on the trans-stilbene derivative. In the case of 4-methoxystilbene, the two regioisomers are obtained at almost the same proportion (Table 1, entry 3), indicating the methoxy group had no influence on the olefin insertion step. However, an effect on regioselectivity was observed when trans-stilbene containing a strong electron-withdrawing group was use (Table 1, entry 4). In this case, the phenyl group from the $\mathrm{Ph}-\mathrm{Pd}$ complex migrates preferentially to the same carbon of the double bond to which the phenyl is bonded. This result can be explained by the fact that the major pathway for syn insertion is the selective migration of the aryl moiety onto the more charge-deficient carbon of the alkene, which is the $\beta$-carbon in the case of an aryl with a nitro group in the para position.

In order to evaluate the reactivity of different aryl halides, competition experiments were carried out (Table 2). A mixture of aryl bromide and bromobenzene were subjected to the Heck reaction protocol with transstilbene and activity was evaluated at low conversions $(<20 \%)$, to compare initial rates. Similar reactivity was 


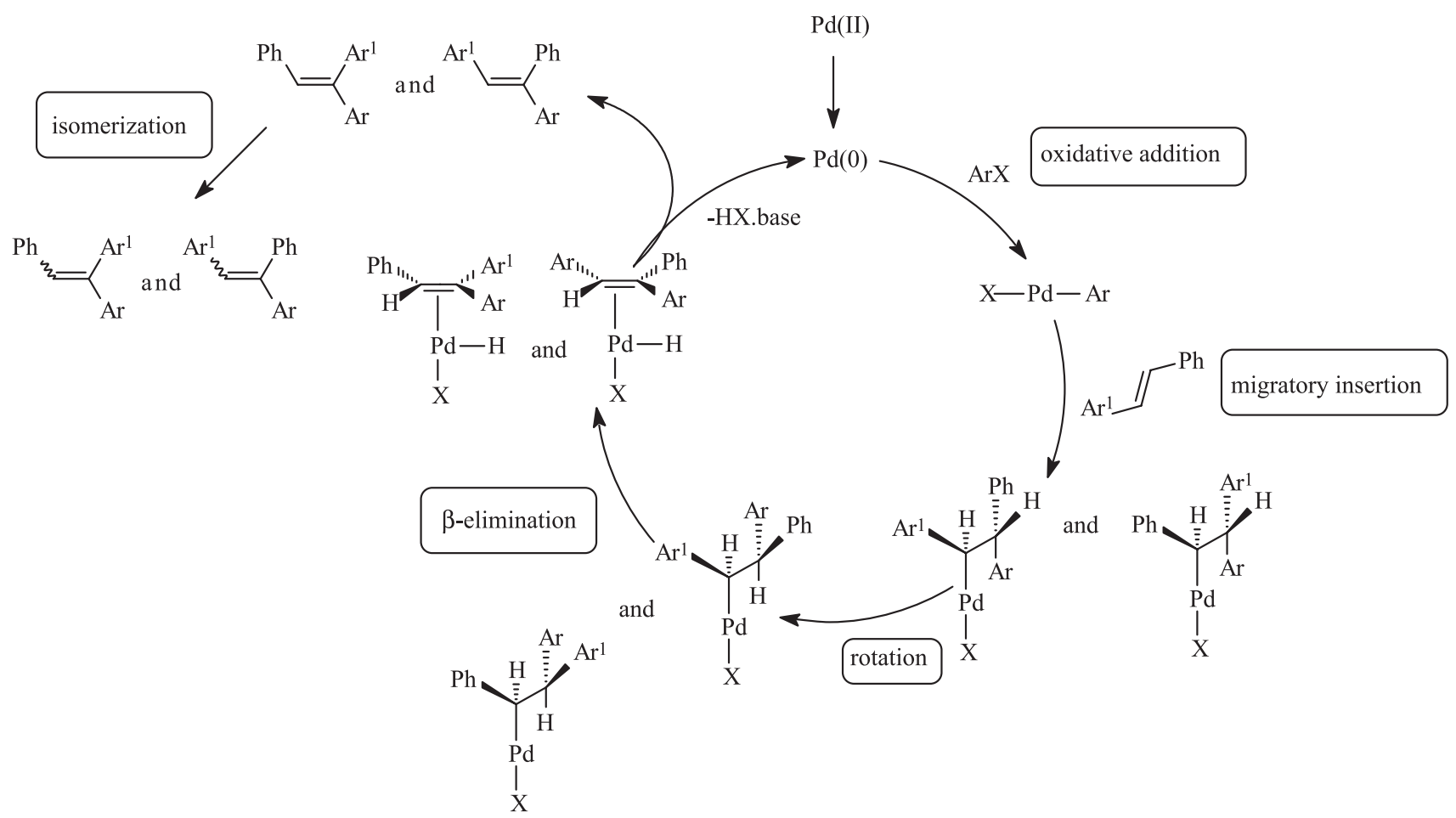

Scheme 1. Simplified catalytic cycle for the Heck reaction with trans-stilbene derivatives (tri-o-tolylphosphine ligands are omitted for clarity).

Table 2. Pd-catalyzed competitive Heck reaction of trans-stilbene with different aryl bromides ${ }^{\mathrm{a}}$<smiles>[R]C=Cc1ccc([R])cc1</smiles>

\begin{tabular}{lcccc}
\hline entry & $\mathrm{R}^{1}$ & $\mathrm{R}^{2}$ & Selectivity $\mathbf{1 : 2}$ & Selectivity $\mathbf{2 : 3}$ \\
\hline 1 & $\mathrm{Ph}$ & $\mathrm{OMe}$ & $49: 51$ & $96: 4$ \\
2 & $\mathrm{Ph}$ & $\mathrm{COMe}$ & $59: 41$ & $54: 46$ \\
3 & $\mathrm{Ph}$ & $\mathrm{CN}$ & $69: 31$ & $16: 84$ \\
4 & $\mathrm{Ph}$ & $\mathrm{CF}_{3}$ & $58: 42$ & $39: 61$ \\
5 & $\mathrm{H}$ & $\mathrm{COMe}$ & $34: 66$ & $100: 0$ \\
\hline
\end{tabular}

${ }^{a}$ Average of 2 runs; reaction conditions: stilbene $(0.5 \mathrm{mmol})$, bromobenzene $(0.25 \mathrm{mmol})$, aryl bromide $(0.25 \mathrm{mmol}), \mathrm{K}_{2} \mathrm{CO}_{3}(1 \mathrm{mmol}), \mathrm{Pd}(\mathrm{OAc})_{2}(2 \mathrm{~mol} \%)$, $\mathrm{P}(o \text {-tol })_{3}(4 \mathrm{~mol} \%), \mathrm{DMF}(3 \mathrm{~mL}), 130^{\circ} \mathrm{C}, 5 \mathrm{~h}$, all reactions were performed up to $20 \%$ conversion.

observed for coupling trans-stilbene with 4-bromoanisol or bromobenzene (Table 2, entry 1). However, the coupling product obtained from the reaction with bromobenezene is preferentially formed over those obtained from aryl bromides containing an electron-withdrawing group (Table 2, entries 2-4). It is worthwhile to mention that when aryl bromides containing an electron-withdrawing group was use, a significant amount of homocoupling product is formed. Oxidative addition has been also postulated as the first step in the catalytic cycle for the homocoupling of aryl halides. ${ }^{23}$ Therefore, as expected for the aryl bromides containing an electron-withdrawing group, the oxidative addition is faster but homocoupling of aryl bromide is the major reaction (Table 2, entries 3 and 4). For purpose of comparison, the competitive reaction of 4-bromoacethophenone with bromobenzene using styrene as olefin partner instead of stilbene was carried out (Table 2, entries 5 and 6). In the presence of styrene, no homocoupling product was observed, and the Heck coupling product obtained from the activated aryl halide was the major product (Table 2, entry 5). These results clearly indicate that oxidative addition is not the rate 
limiting step, which is more likely due to steric effects from the diarylalkene in the coordination and/or migratory insertion steps. In order to confirm this conclusion, the Heck reaction of bromobenzene with iodobenzene was compared. The reaction of the aryl halides with stilbene was carried out separately and analyzed at the same reaction time (6 h). Indeed, bromobenzene gave a two times faster reaction rate for the formation of the Heck coupling product. Again, we were able to confirm the tendency of activated halides to form homocoupling products. For the bromobenezene, the Heck coupling:homocoupling ratio observed was 93:7 and for the iodobenzene was 43:57.

The effect of a substituent group on the stilbene derivative was also evaluated (Scheme 2). A mixture of trans-1-aryl-2-phenylethene and trans-stilbene was each subjected to the Heck reaction protocol with bromobenzene, and the activity was evaluated at low conversions $(<20 \%)$, to compare initial rates. Similar reactivity was observed for coupling bromobenzene with trans-4-metoxystilbene or trans-stilbene (51:49). However, the coupling product obtained from the reaction, trans-1-aryl-2-phenylethene containing a nitro group, is slightly preferred over those obtained from trans-stilbene (62:38).

In addition, we compared 1,1- and 1,2-diphenylethene (Scheme 3). A mixture of 1,1-diphenylethene and transstilbene was each subjected to the Heck reaction protocol with 4-bromoanisol. No significant difference was observed and similar reactivity was obtained for the two olefins, as indicated by the fact that 1,2-diphenyl-1-arylethene and 1,1-diphenyl-2-arylethene were obtained at a ratio of 45:55.

We have recently described a sequential and selective Pd-catalyzed double-Heck arylation of ethylene that results in non-symmetrical nitro-stilbene analogues of trans-resveratrol at excellent yields. ${ }^{24} \mathrm{~A}$ catalytic system consisting of $\mathrm{Pd}(\mathrm{OAc})_{2}$ and $\mathrm{P}(\mathrm{o}-\mathrm{tol})_{3}$ became possible to carry out two consecutive Heck arylations without losing activity from the first to the second Heck reaction. This approach is also used in the present work to obtain a trisubstituted olefin from styrene in a one pot protocol (Scheme 4). Arylation of styrene was carried out at $80^{\circ} \mathrm{C}$ to
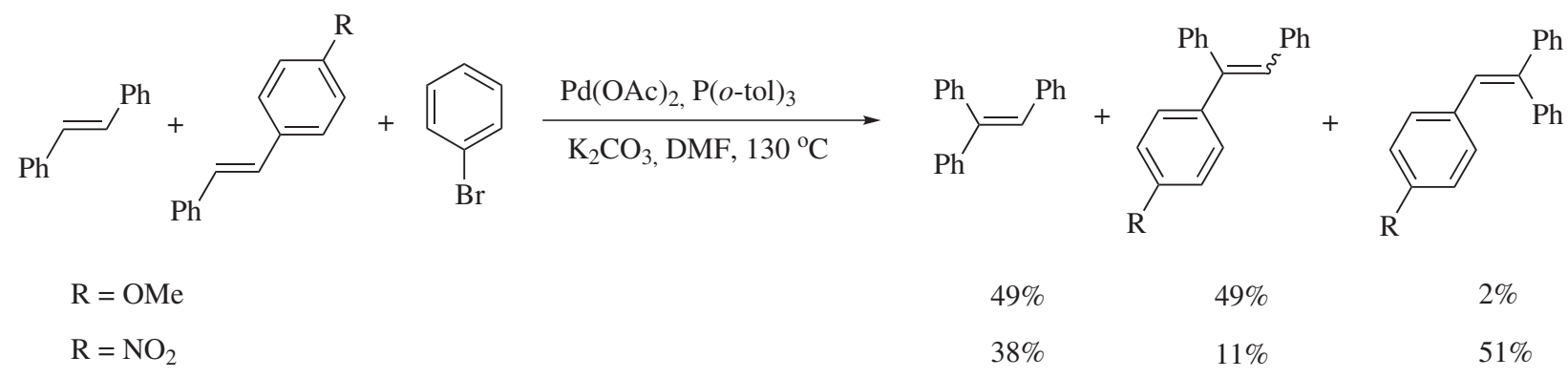

Scheme 2. Pd-catalyzed competitive Heck reaction of bromobenzene with different trans-stilbene derivatives.

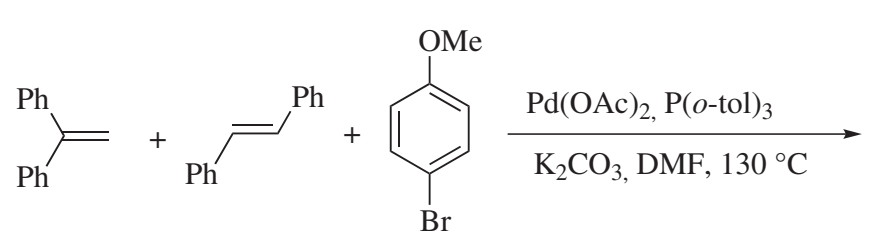

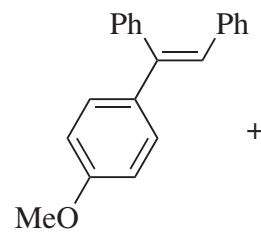

$45 \%$

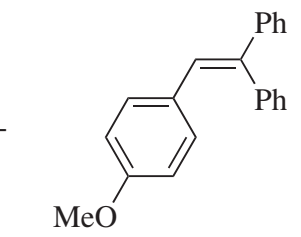

$55 \%$

$$
E / Z=82: 18
$$

Scheme 3. Pd-catalyzed competitive Heck reaction of 1,1-diphenylethene and stilbene with $p$-bromoanisole.

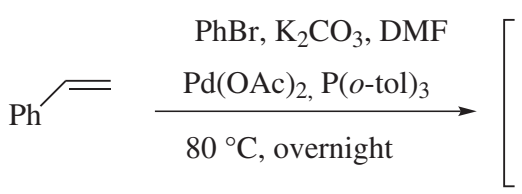

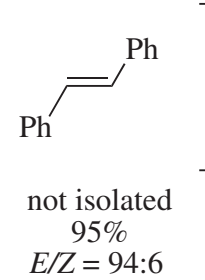

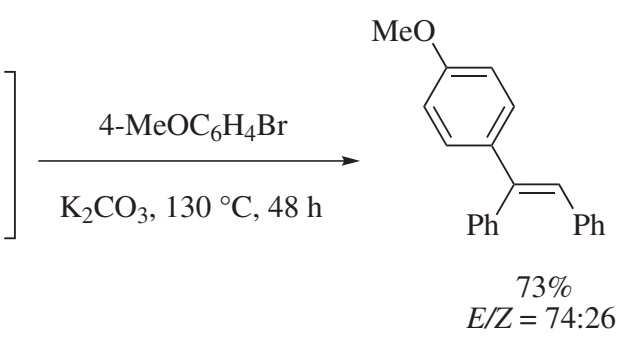

Scheme 4. Pd-catalyzed Heck double-arylation of styrene. 
give the stilbene. After the first Heck arylation, no isolation or additional catalyst loading is required for the second Heck arylation reaction. For the second Heck reaction, the only difference was the addition of 4-bromoanisol and base and the raising of the temperature to $130{ }^{\circ} \mathrm{C}$, resulting in the trisubstituted olefin at $73 \%$ yield. Because the stilbene was obtained at an $E: Z$ ratio of $94: 6$, regioselectivity obtained for this trisubstituted olefin (74:26) was lower than that obtained using pure trans-stilbene (83:17, Table 1, entry 2). The main by-product obtained was a triphenylethene generated from the coupling of stilbene with unreacted bromobenzene.

\section{Conclusions}

In summary, the Heck arylation of diarylethylenes giving triarylolefins with good to excellent yields wiht a simple $\mathrm{Pd}(\mathrm{OAc})_{2} / \mathrm{P}(o \text {-tol })_{3}$ catalytic system is described. The electron withdrawing group substituent in the para position of stilbene affect the regioselectivity of the reaction is also described. In this case, the phenyl group from the $\mathrm{Ph}$-Pd complex migrates preferentially to the same carbon of the double bond to which the phenyl is bonded. Through competitive Heck reactions, it was possible to determine that $(i)$ oxidative addition is not involved in the rate-determining step; and (ii) electron-withdrawing groups in the olefin slightly increase the reaction rate. Finally, a one-pot Heck double arylation of styrene, resulting in 1,2-diphenyl-1-(4-methoxyphenyl)ethene at $73 \%$ yield is described.

\section{Supplementary Information}

Supplementary data is available free of charge at http://jbcs.sbq.org.br as a pdf file.

\section{Acknowledgements}

We thank the Conselho Nacional de Desenvolvimento Científico e Tecnológico (CNPq), the Coordenação de Aperfeiçoamento de Pessoal de Nível Superior (CAPES), the Fundação de Amparo à Pesquisa do Estado do Rio Grande do Sul (PRONEX-FAPERGS) and the Instituto Nacional de Ciência e Tecnologia de Catálise (INCTCatalise) for partial financial support. We also thank the CNPq (J.L. and S.P.) for scholarships.

\section{References}

1. Beletskaya, I. P.; Cheprakov, A. V.; Chem. Rev. 2000, 100, 3009.

2. Flynn, A. B.; Ogilvie, W. W.; Chem. Rev. 2007, 107, 4698.

3. MorenoManas, M.; Pleixats, R.; Roglans, A.; Synlett 1997, 1157.

4. Masllorens, J.; Moreno-Manas, M.; Pla-Quintana, A.; Pleixats, R.; Roglans, A.; Synthesis 2002, 1903.

5. MorenoManas, M.; Perez, M.; Pleixats, R.; Tetrahedron Lett. 1996, 37, 7449 .

6. Blettner, C. G.; Konig, W. A.; Stenzel, W.; Schotten, T.; Tetrahedron Lett. 1999, 40, 2101.

7. Gurtler, C.; Buchwald, S. L.; Chem.--Eur. J. 1999, 5, 3107.

8. Ohff, M.; Ohff, A.; Milstein, D.; Chem. Commun. 1999, 357.

9. Littke, A. F.; Fu, G. C.; J. Am. Chem. Soc. 2001, 123, 6989.

10. Kondolff, I.; Doucet, H.; Santelli, M.; Tetrahedron Lett. 2003, 44, 8487.

11. Nejjar, A.; Pinel, C.; Djakovitch, L.; Adv. Synth. Catal. 2003, 345,612 .

12. Beller, M.; Riermeier, T. H.; Eur. J. Inorg. Chem. 1998, 29.

13. Berthiol, F.; Doucet, H.; Santelli, M.; Eur. J. Org. Chem. 2003, 1091.

14. Bolliger, J. L.; Blacque, O.; Frech, C. M.; Chem.--Eur. J. 2008, 14, 7969 .

15. Nadri, S.; Joshaghani, M.; Rafiee, E.; Organometallics 2009, 28,6281 .

16. Nunes, C. M.; Limberger, J.; Poersch, S.; Seferin, M.; Monteiro, A. L.; Synthesis 2009, 2761.

17. Nunes, C. M.; Steffens, D.; Monteiro, A. L.; Synlett 2007, 103.

18. Calo, V.; Nacci, A.; Monopoli, A.; Cotugno, P.; Angew. Chem., Int. Ed. 2009, 48, 6101.

19. Ozawa, F.; Kubo, A.; Hayashi, T.; J. Am. Chem. Soc. 1991, 113, 1417.

20. Cabri, W.; Candiani, I.; Acc. Chem. Res. 1995, $28,2$.

21. Heck, R. F.; Acc. Chem. Res. 1979, 12, 146.

22. Knowles, J. P.; Whiting, A.; Org. Biomol. Chem. 2007, 5, 31.

23. Hennings, D. D.; Iwama, T.; Rawal, V. H.; Org. Lett. 1999, 1, 1205.

24. Nobre, S. M.; Muniz, M. N.; Seferin, M.; Silva, W. M. D.; Monteiro, A. L.; Appl. Organometal. Chem. 2011, 25, 289.

Submitted: December 21, 2010

Published online: March 29, 2011 


\title{
Pd-Catalyzed Heck Reactions of Aryl Bromides with 1,2-Diarylethenes
}

\author{
Jones Limberger, Silvia Poersch and Adriano L. Monteiro* \\ Laboratory of Molecular Catalysis, Instituto de Química, Universidade Federal do Rio Grande do Sul (UFRGS), \\ Av. Bento Gonçalves, 9500, CP 15003, 91501-970 Porto Alegre-RS, Brazil
}

$$
\underset{\mathrm{Ph}}{\mathrm{Ph}}=\mathrm{Ph}
$$

1,1,2-triphenylethene: white solid, $\mathrm{mp} 70-73{ }^{\circ} \mathrm{C}$ $\left(72-73{ }^{\circ} \mathrm{C}\right){ }^{7} .{ }^{1} \mathrm{H} \mathrm{NMR}{ }^{1,2}\left(300 \mathrm{MHz}, \mathrm{CDCl}_{3}\right) \delta$ ppm 6.96 (s, 1H), 7.06-7.00 (m, 2H), 7.16-7.07 (m, 3H), 7.24-7.17 $(\mathrm{m}, 2 \mathrm{H}), 7.39-7.26(\mathrm{~m}, 8 \mathrm{H}){ }^{13} \mathrm{C} \mathrm{NMR}^{1,2}\left(75 \mathrm{MHz}, \mathrm{CDCl}_{3}\right)$ $\delta$ ppm 126.7, 127.4, 127.5, 127.6, 127.9, 128.1, 128.2, 128.6, 129.5, 130.4, 137.3, 140.3, 142.5, 143.4. GC-MS m/z (\%): 257 (21), 256 (100, M+), 241 (21), 204 (9), 178 (53), 165 (21), 152 (13).

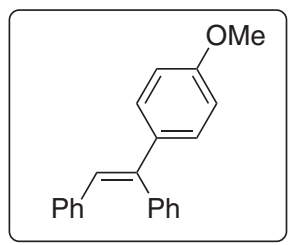

1-methoxy-4-((E)-1,2-diphenylvinyl)benzene: oil. ${ }^{1} \mathrm{H} \mathrm{NMR}^{2-4}\left(300 \mathrm{MHz}, \mathrm{CDCl}_{3}\right) \delta \mathrm{ppm} 3.82(\mathrm{~s}, 3 \mathrm{H}), 6.85(\mathrm{~d}$, 2H, J 8.93 Hz), 6.90 (s, 1H), 7.03-6.98 (m, 2H), 7.15-7.07 (m, 3H), 7.23-7.18 (m, 2H), 7.26 (d, 2H, J 8.92 Hz), 7.35$7.30(\mathrm{~m}, 1 \mathrm{H}) .{ }^{13} \mathrm{C}-\mathrm{NMR}^{4}\left(75 \mathrm{MHz}, \mathrm{CDCl}_{3}\right) \delta$ ppm 55.1, $113.5,126.3,126.4,127.3,127.8,128.5,128.7,129.3$, 130.3, 135.9, 137.5, 140.4, 142.0, 159.1. GC-MS m/z (\%): 287 (24), 286 (100, M+), 255 (12), 228 (11), 215 (9), 178 (16), 165 (26), 126 (12), 120 (21).

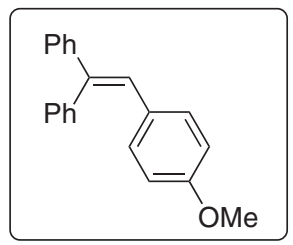

1-methoxy-4-(2,2-diphenylvinyl)benzene: white solid obtained with with $80 \%$ of purity $(20 \%$ of 4-methoxystilbene). ${ }^{1} \mathrm{H} \mathrm{NMR}^{5,6}\left(300 \mathrm{MHz}, \mathrm{CDCl}_{3}\right) \delta \mathrm{ppm}$

*e-mail: adriano.monteiro@ufrgs.br
3.75 (s, 3H), 6.68 (d, 2H, J $8.80 \mathrm{~Hz}), 6.92(\mathrm{~s}, 1 \mathrm{H}), 6.96$ (d, 2H, J $8.88 \mathrm{~Hz}$ ), 7.38-7.20 (m, 10H). GC-MS m/z (\%): 287 (22), 286 (100, M+), 271 (7), 253 (7), 239 (8), 228 (9), 215 (6), 178 (8), 165 (38).

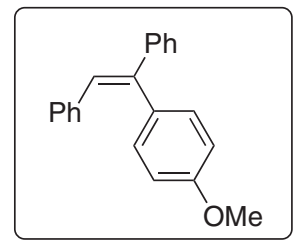

1-((Z)-1-(4-methoxyphenyl)-2-phenylvinyl)benzene: GC-MS m/z (\%): 287 (24), $286\left(100, \mathrm{M}^{+}\right), 253$ (11), 228 (10), 215 (9), 178 (17), 165 (25), 126 (11), 119 (16).

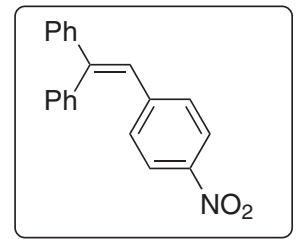

1-(2-(4-nitrophenyl)-1-phenylvinyl)benzene: yellow solid , mp 148- $151{ }^{\circ} \mathrm{C}\left(148-150{ }^{\circ} \mathrm{C}\right)^{5} .{ }^{1} \mathrm{H} \mathrm{NMR}^{1}(300 \mathrm{MHz}$, $\left.\mathrm{CDCl}_{3}\right) \delta \mathrm{ppm} 7.00(\mathrm{~s}, 1 \mathrm{H}), 7.14(\mathrm{~d}, 2 \mathrm{H}, \mathrm{J} 8.97 \mathrm{~Hz}), 7.21-$ $7.16(\mathrm{~m}, 2 \mathrm{H}), 7.49-7.30(\mathrm{~m}, 8 \mathrm{H}), 7.98$ (d, 2H, J $8.91 \mathrm{~Hz})$. ${ }^{13} \mathrm{C} \mathrm{NMR}^{1,5}\left(75 \mathrm{MHz}, \mathrm{CDCl}_{3}\right) \delta \mathrm{ppm} 123.2,125.6,127.8$, 128.2, 128.3, 128.4, 128.9, 129.9, 130.1, 139.2, 142.3, 144.2, 145.8, 146.9. GC-MS m/z (\%): 302 (22), 301 (100, $\mathrm{M}^{+}$), 254 (30), 253 (38), 239 (27), 178 (18), 165 (27), 126 (16), 113 (11).

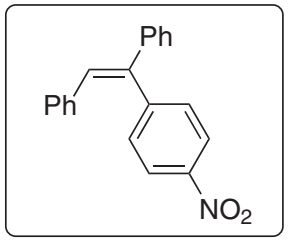

1-((Z)-2-(4-nitrophenyl)-2-phenylvinyl)benzene: yellow crystals , mp 160-163 ${ }^{\circ} \mathrm{C} .{ }^{1} \mathrm{H}$ NMR $\left(300 \mathrm{MHz}, \mathrm{CDCl}_{3}\right)$ $\delta$ ppm 7.08-7.01 (m, 2H), 7.10 (s, 1H), 7.22-7.17 (m, 3H), 
7.32-7.26 (m, 2H), 7.38-7.34 (m, 2H), 7.40 (dd, 2H, J 6.94, $1.86 \mathrm{~Hz}$ ), 8.19 (dd, 2H, J 6.88, $1.88 \mathrm{~Hz}) .{ }^{13} \mathrm{C}$ NMR $(75$ $\left.\mathrm{MHz}, \mathrm{CDCl}_{3}\right) \delta$ ppm 123.7, 127.4, 127.5, 128.0, 128.2, $128.4,129.4,130.1,131.4,136.3,140.4,142.0,146.9$, 147.6. GC-MS (IE, $70 \mathrm{eV}) \mathrm{m} / \mathrm{z}$ (\%): 302 (24), 301 (100, $\left.\mathrm{M}^{+}\right), 253$ (36), 239 (27), 215 (12), 179 (26), 165 (23), 126 (20), 113 (14).

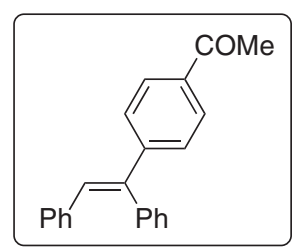

1-(4-((E)-1,2-diphenylvinyl)phenyl)ethanone: GC-MS (IE, $70 \mathrm{eV}) \mathrm{m} / z(\%):^{3} 299(22), 298\left(100, \mathrm{M}^{+}\right), 283(60)$, 255 (27), 253 (29), 239 (28), 207 (20), 178 (15), 152 (9), 120 (14).

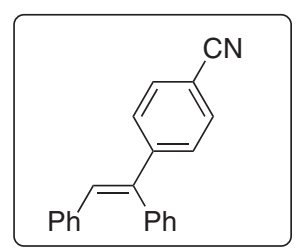

4-((E)-1,2-diphenylvinyl)benzonitrile: GC-MS (IE, $70 \mathrm{eV}) \mathrm{m} / \mathrm{z}(\%):^{3} 282(23), 281\left(100, \mathrm{M}^{+}\right), 266(21), 253$ (11), 203 (17), 179 (28), 165 (14), 126 (13).

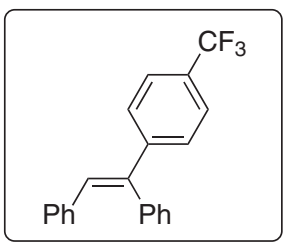

1-(trifluoromethyl)-4-((E)-1,2-diphenylvinyl)benzene: GC-MS (IE, $70 \mathrm{eV}) \mathrm{m} / z(\%):{ }^{2,7} 325$ (22), $324\left(100, \mathrm{M}^{+}\right.$), 309 (17), 283 (21), 253 (21), 246 (16), 178 (35), 165 (17), $126(16)$.

\section{References}

1. Xiao, Q.; Ma, J.; Yang, Y.; Zhang, Y.; Wang, J. B.; Org. Lett. 2009, 11, 4732.

2. Nunes, C. M.; Steffens, D.; Monteiro, A. L.; Synlett 2007, 103.

3. Cacchi, S.; Fabrizi, G.; Goggiamani, A.; Persiani, D.; Org. Lett. 2008, 10, 1597.

4. Wu, M.-J.; Wei, L.-M.; Lin, C.-F.; Leou, S.-P.; Wei, L.-L.; Tetrahedron 2001, 57, 7844.

5. Rodriguez-Escrich, S.; Reddy, K. S.; Jimeno, C.; Colet, G.; Rodriguez-Escrich, C.; Sola, L.; Vidal-Ferran, A.; Pericas, M. A.; J. Org. Chem. 2008, 73, 5340.

6. Huang, L. F.; Chen, C. W.; Luh, T. Y.; Org. Lett. 2007, 9, 3663.

7. Terao, Y.; Nomoto, M.; Satoh, T.; Miura, M.; Nomura, M.; J. Org. Chem. 2004, 69, 6942.

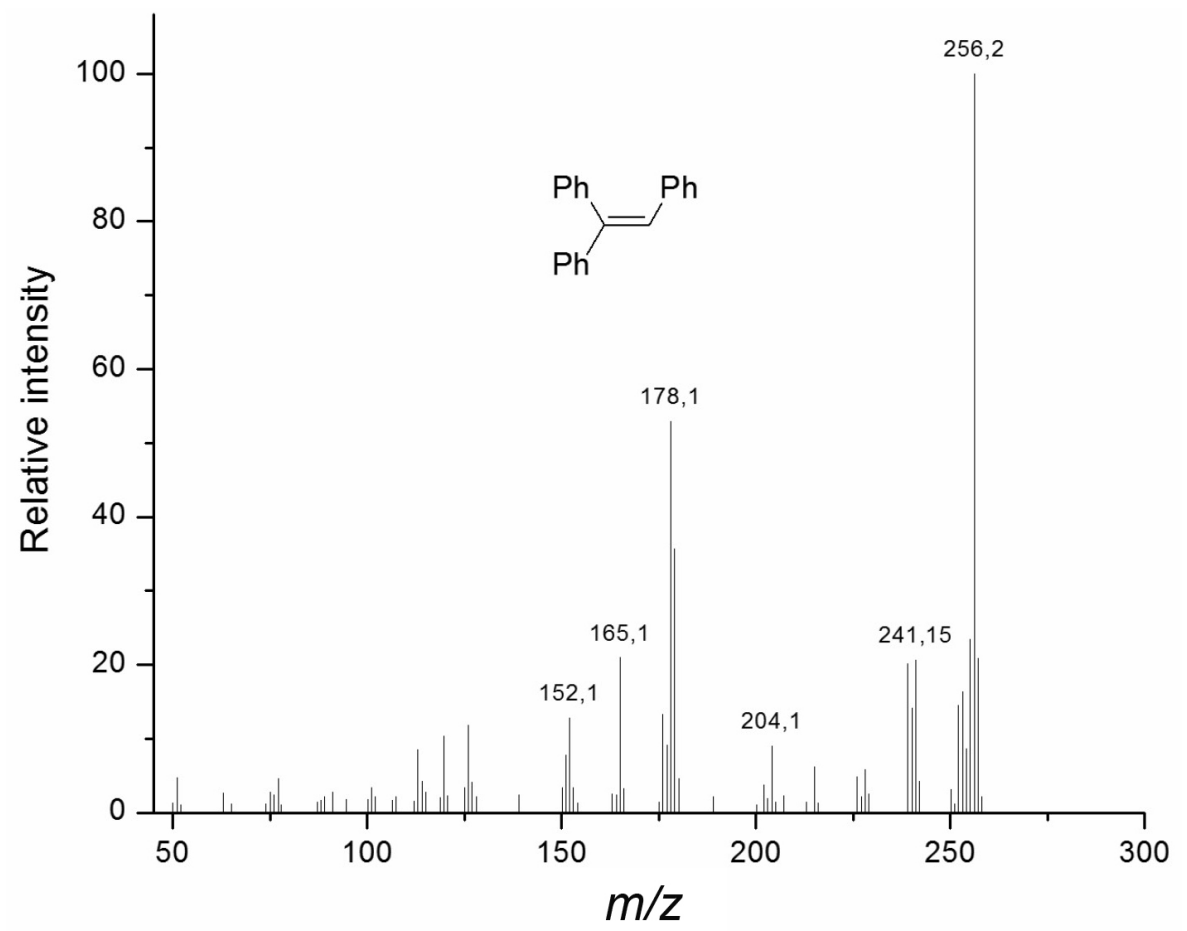

Figure S1. Mass spectrum of 1,1,2-triphenylethene. 


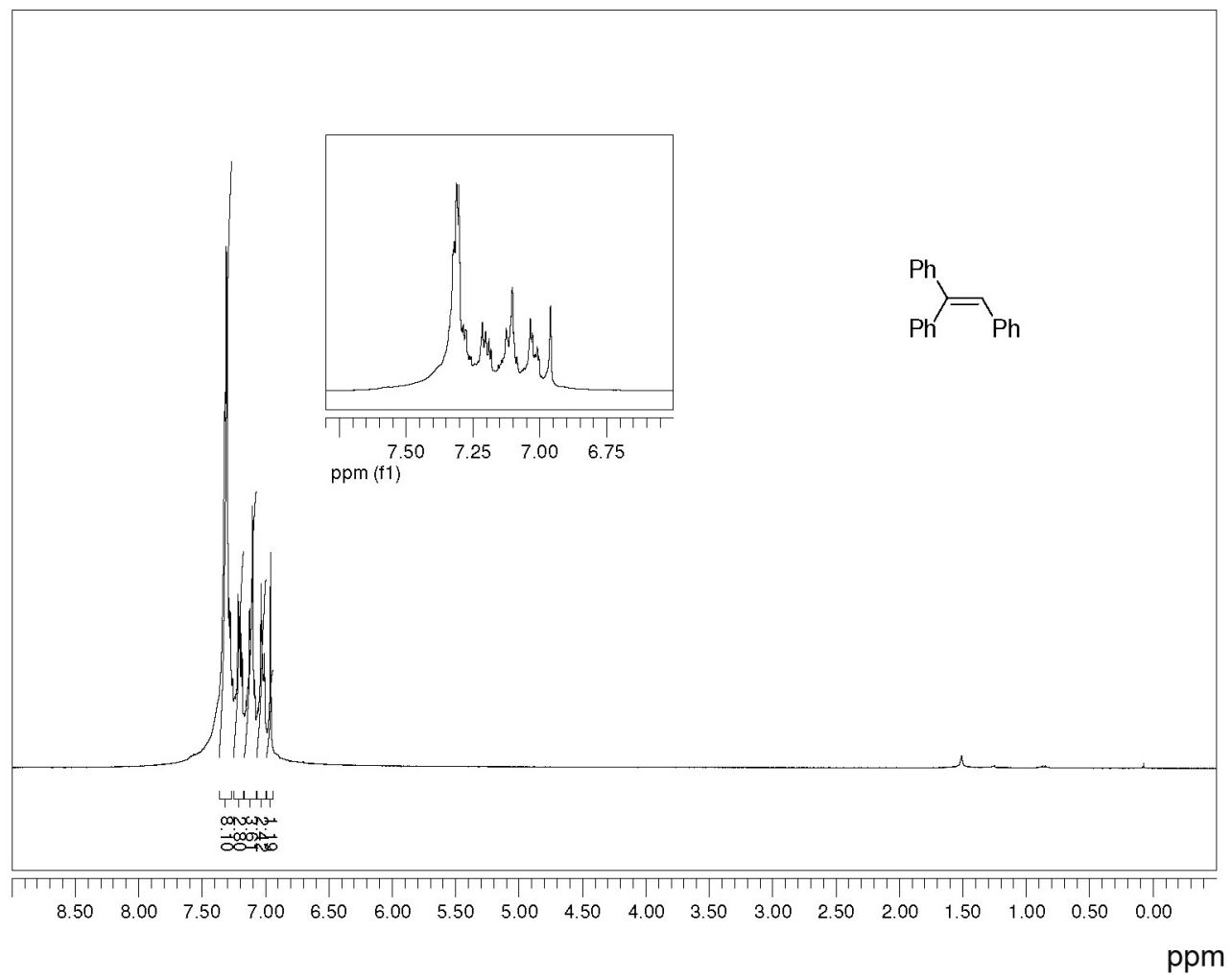

Figure S2. ${ }^{1} \mathrm{H}$ NMR spectrum of 1,1,2-triphenylethene.

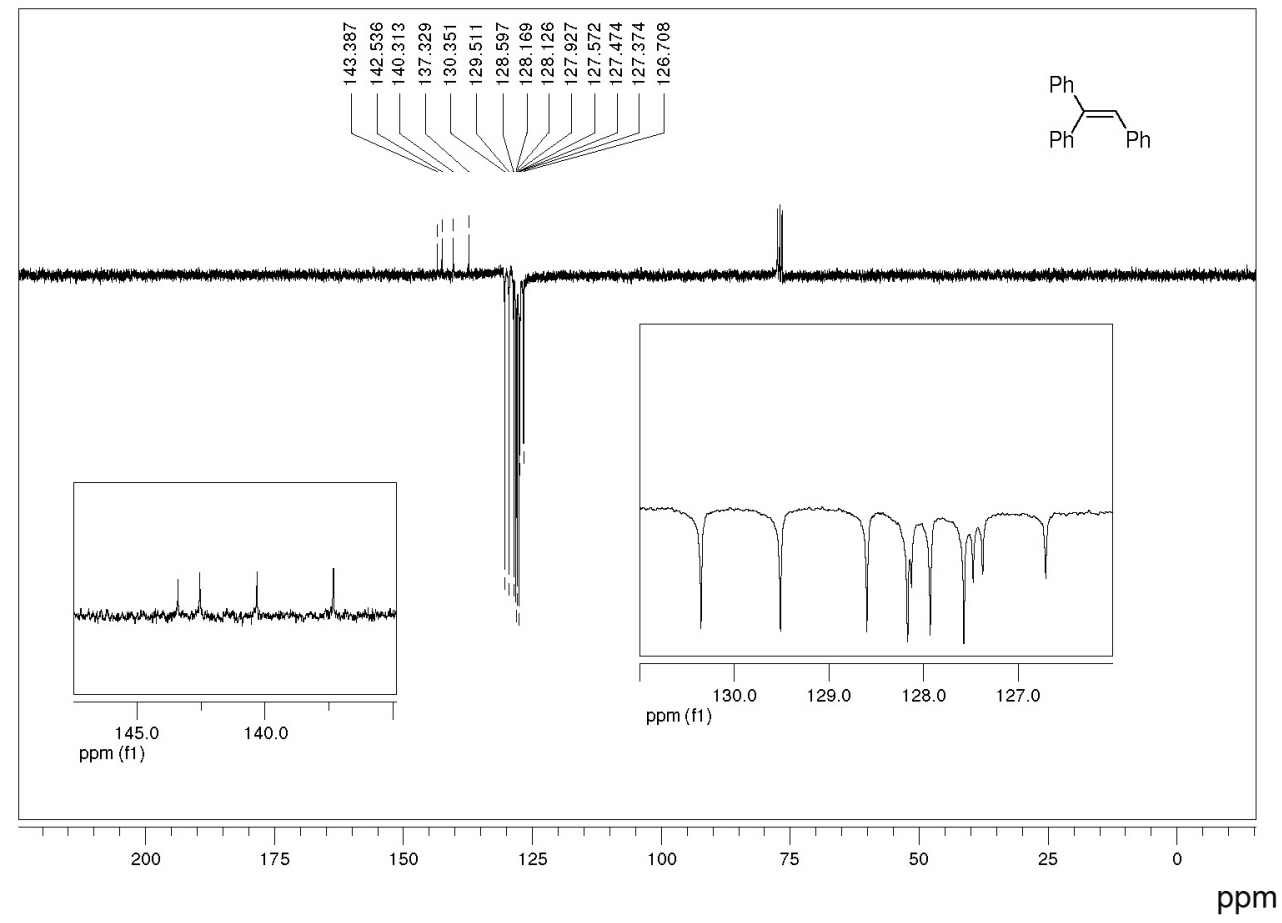

Figure S3. ${ }^{13} \mathrm{C}(\mathrm{APT}) \mathrm{NMR}$ spectrum of 1,1,2-triphenylethene. 


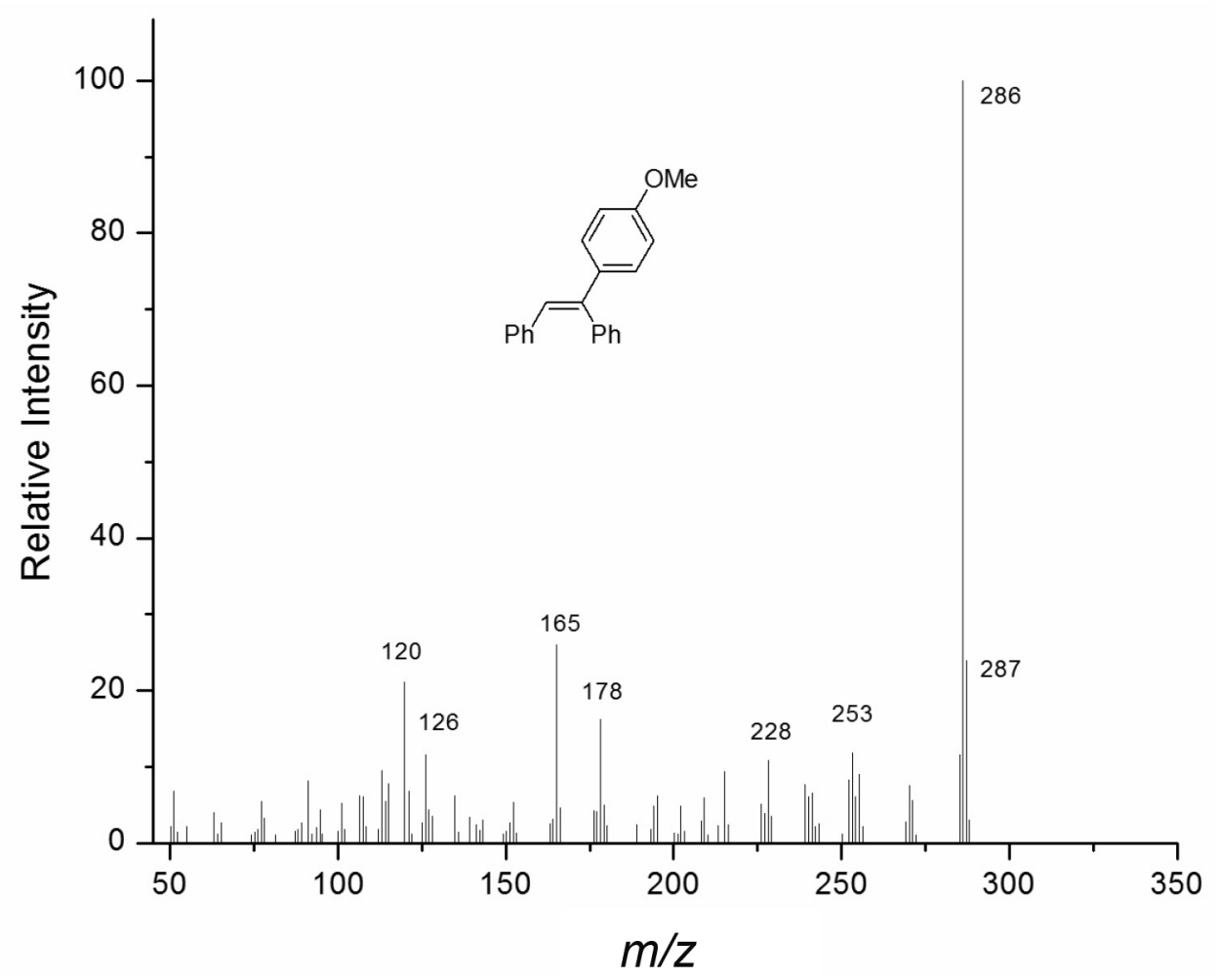

Figure S4. Mass spectrum of 1-methoxy-4-((E)-1,2-diphenylvinyl)benzene.

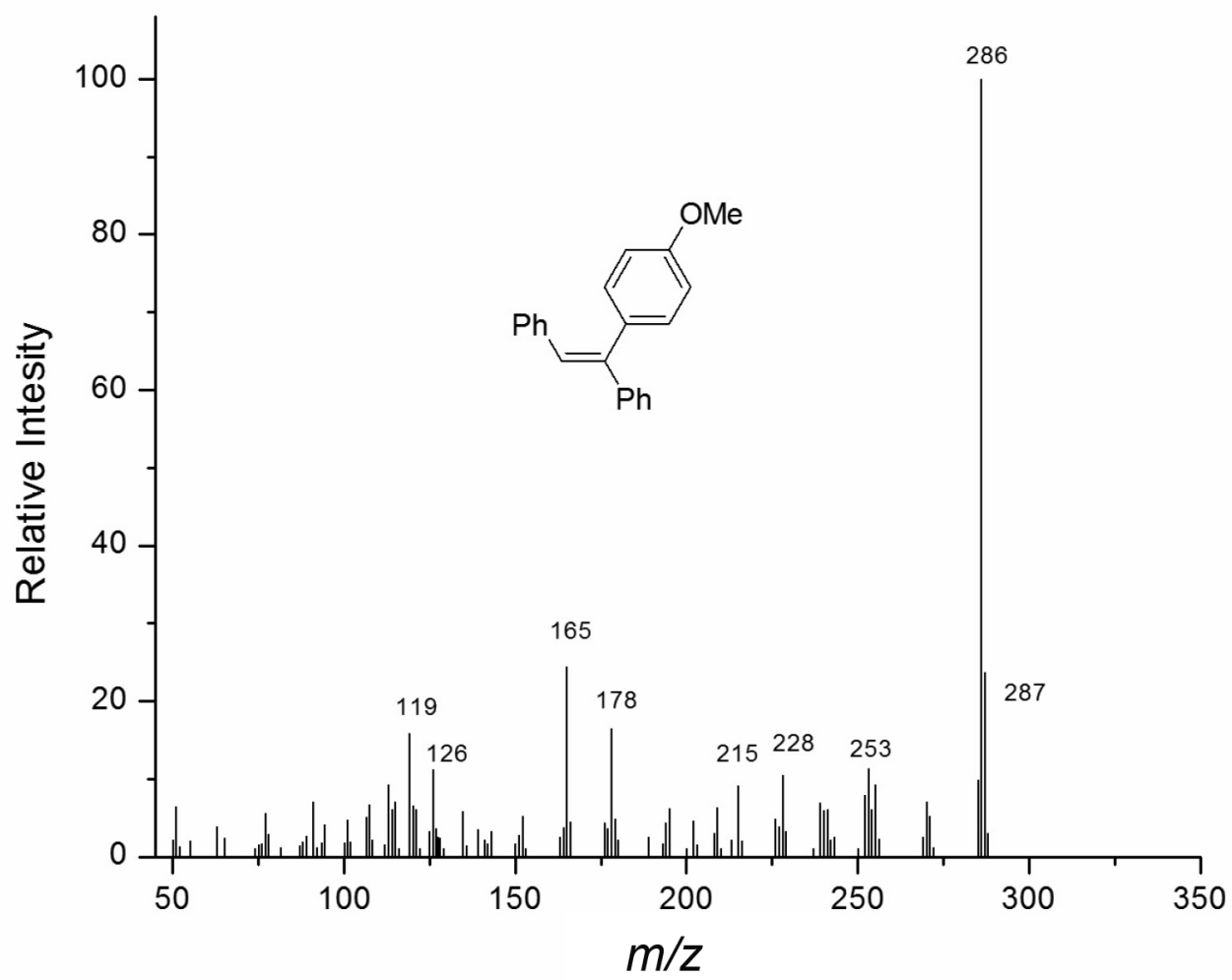

Figure S5. Mass spectrum of 1-((Z)-1-(4-methoxyphenyl)-2-phenylvinyl)benzene. 


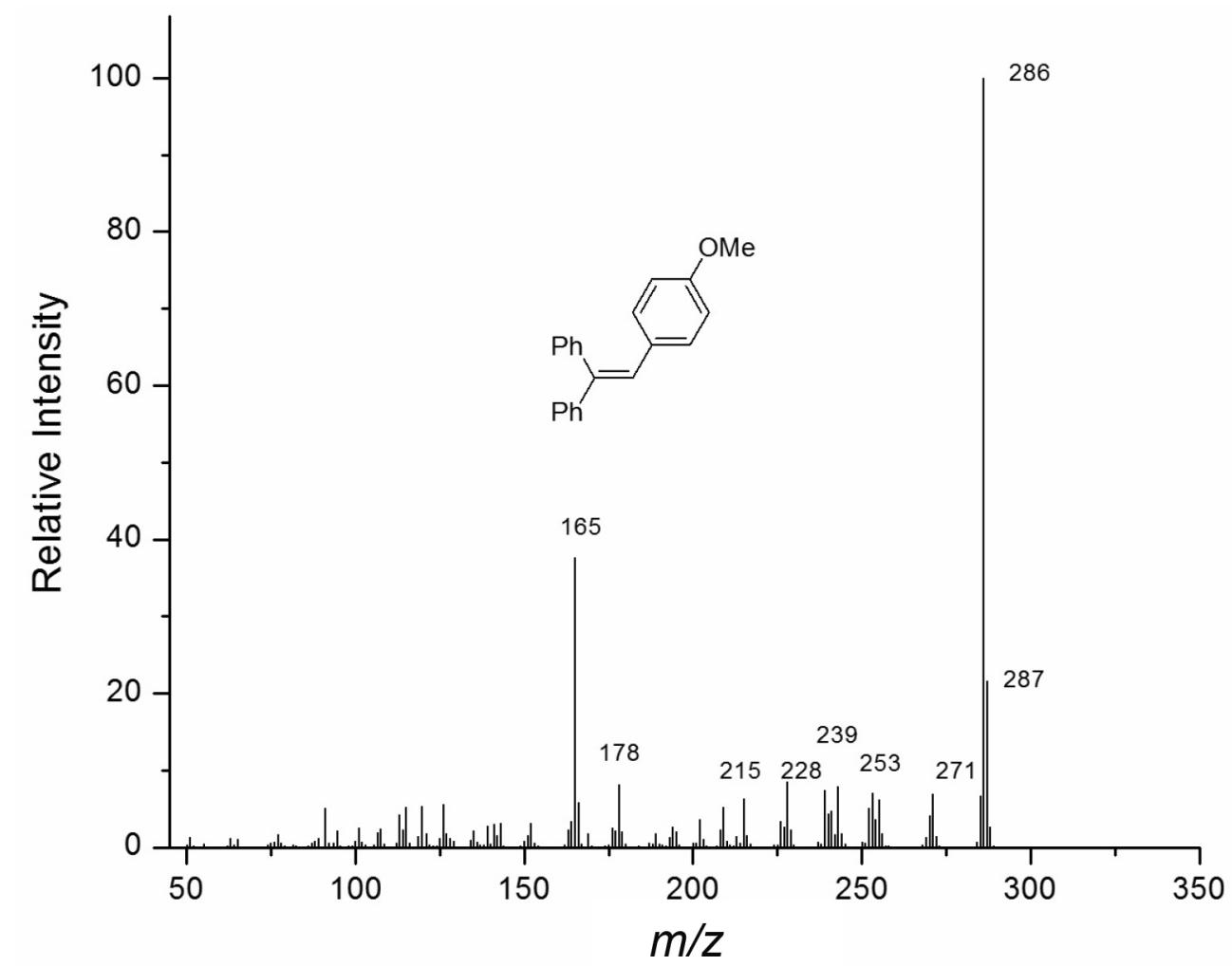

Figure S6. Mass spectrum of 1-methoxy-4-(2,2-diphenylvinyl)benzene.

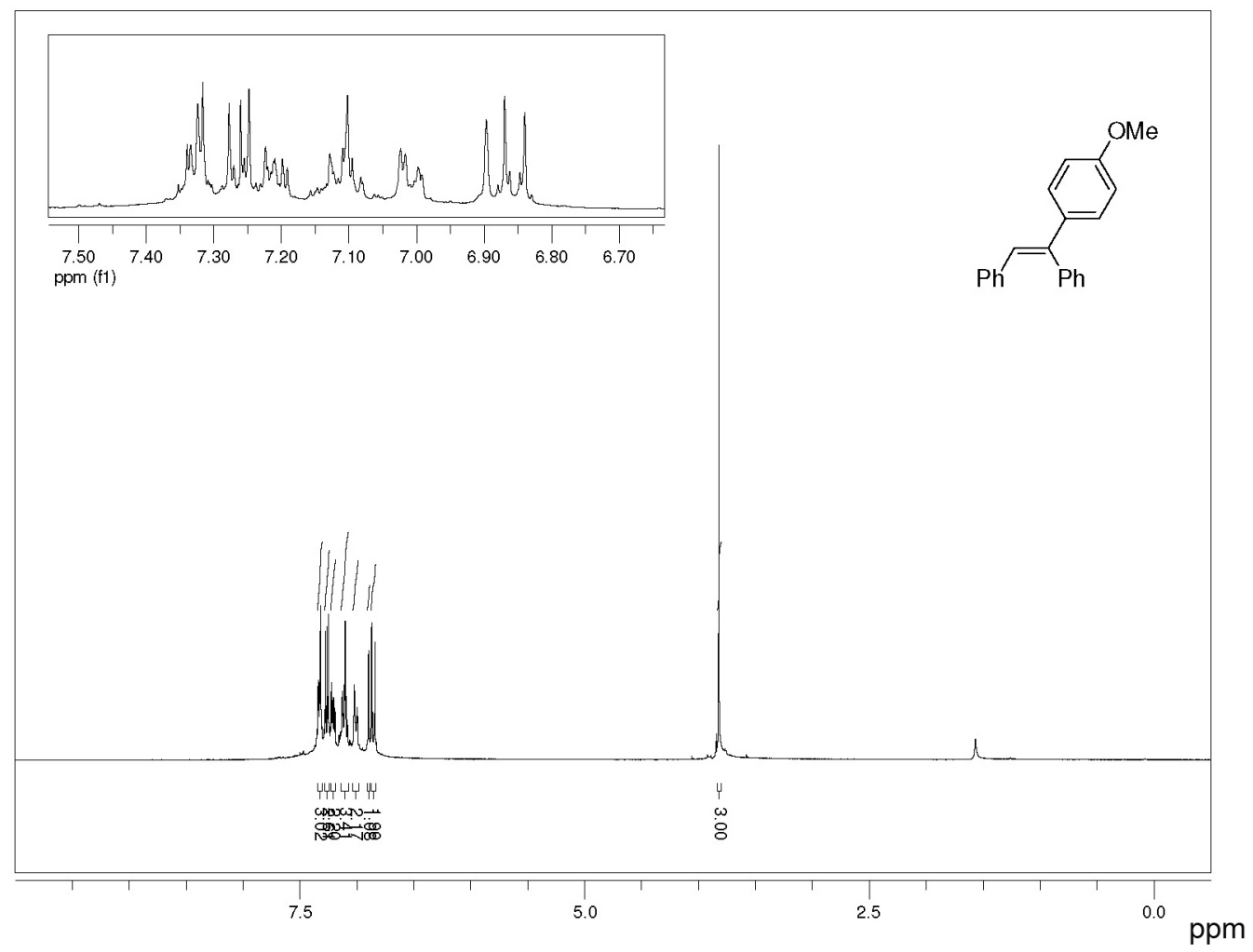

Figure S7. ${ }^{1} \mathrm{H}$ NMR spectrum of 1-methoxy-4-((E)-1,2-diphenylvinyl)benzene. 


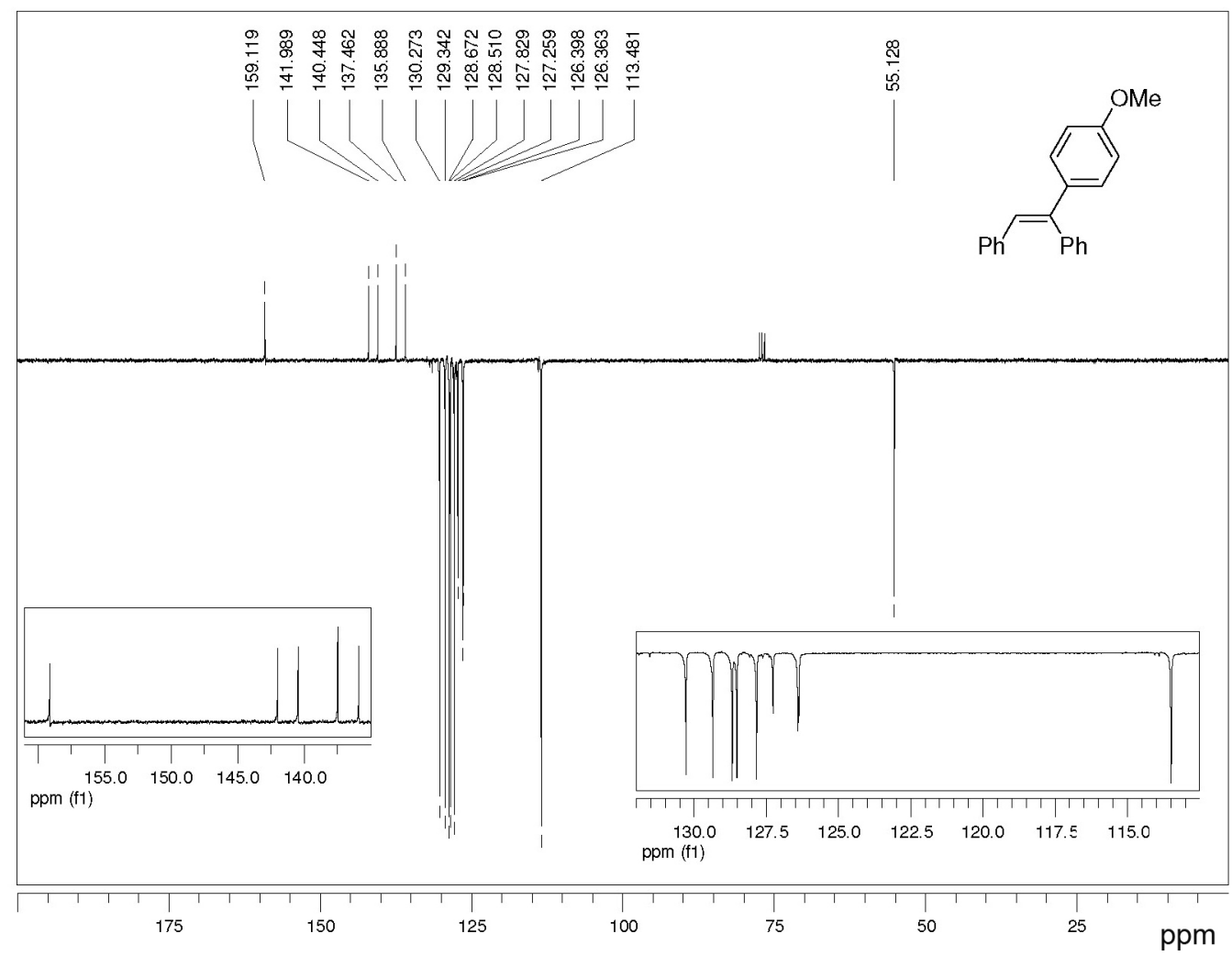

Figure S8. ${ }^{13} \mathrm{C}(\mathrm{APT}) \mathrm{NMR}$ spectrum of 1-methoxy-4-((E)-1,2-diphenylvinyl)benzene.

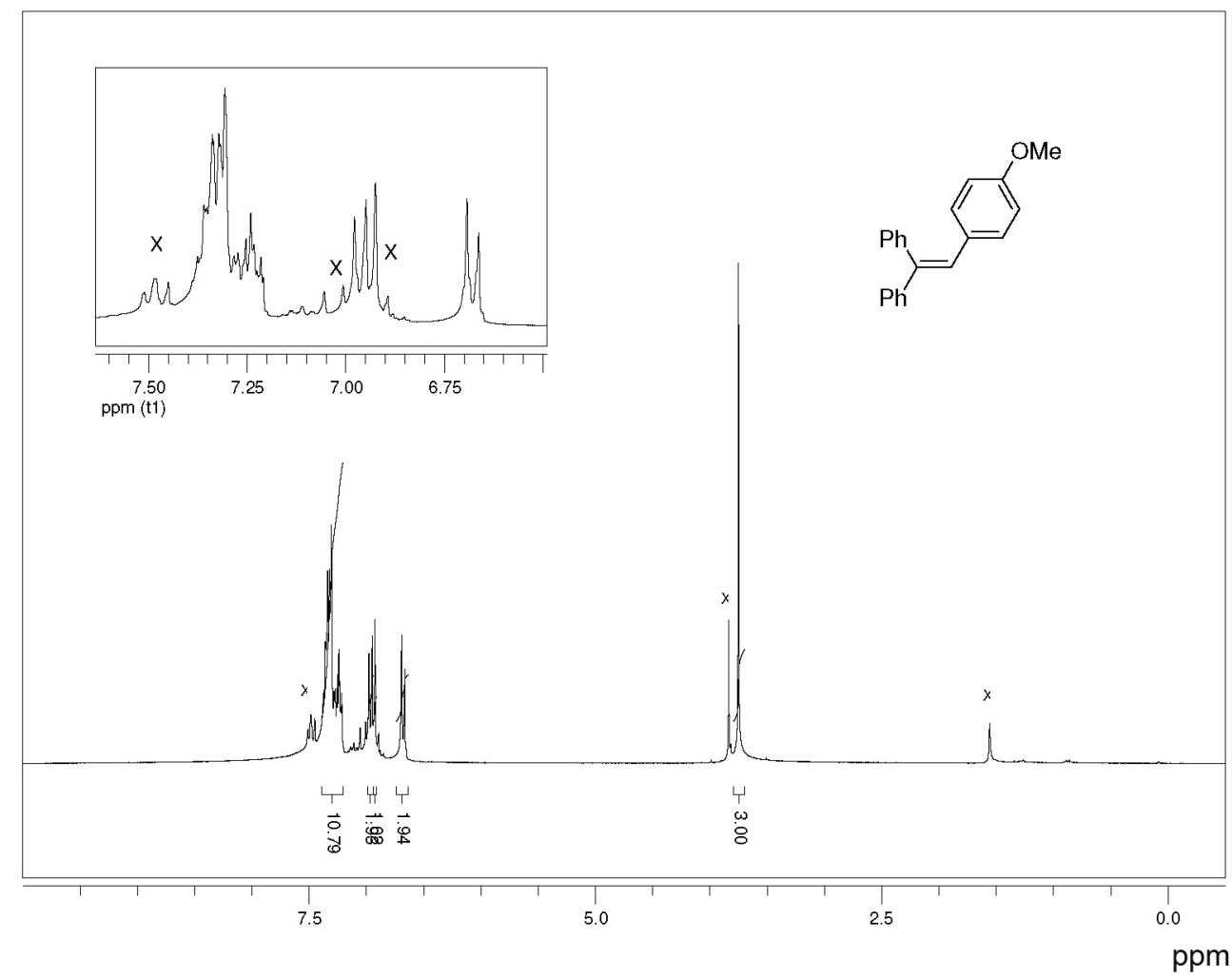

Figure S9. 'H NMR spectrum of 1-methoxy-4-(2,2-diphenylvinyl)benzene with $80 \%$ of purity (20\% of 4-methoxystilbene). 

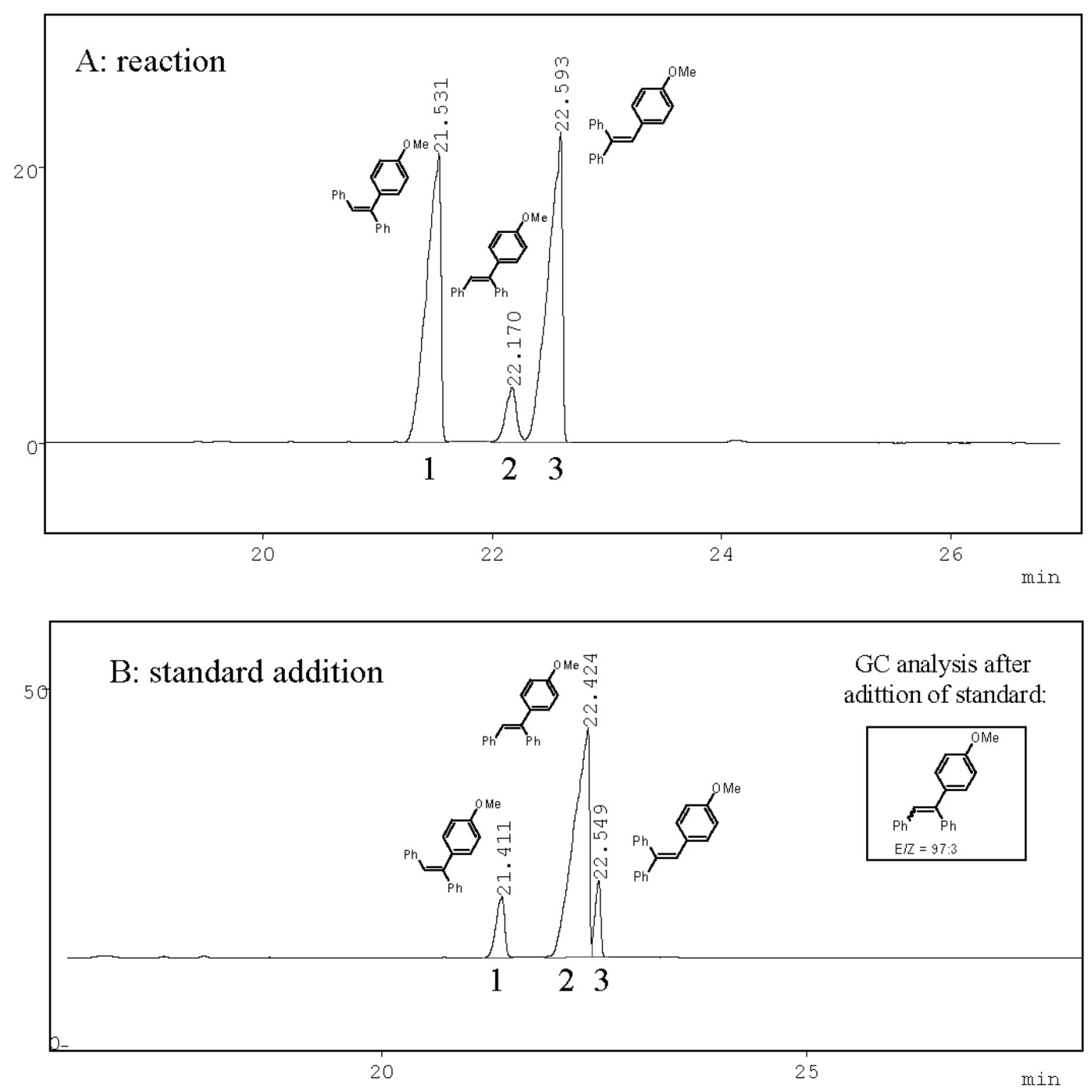

Figure S10. A: GC chromatogram with analysis of Heck reaction between 4-metoxi-stilbene and bromobenzene; B: GC chromatogram of the same sample after addition of 1-methoxy-4-((E)-1,2-diphenylvinyl)benzene (97\%). 


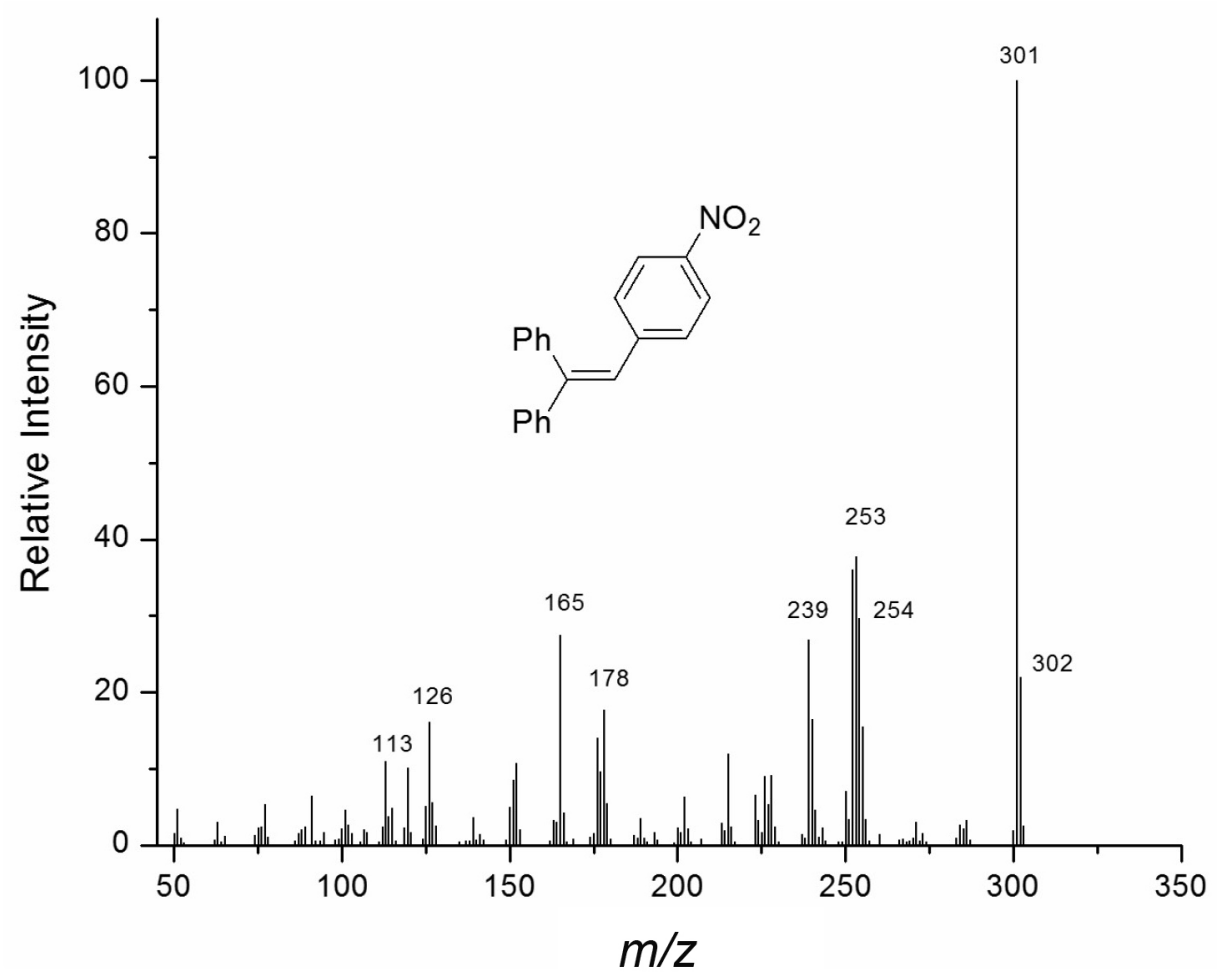

Figure S11. Mass spectrum of 1-(2-(4-nitrophenyl)-1-phenylvinyl)benzene.

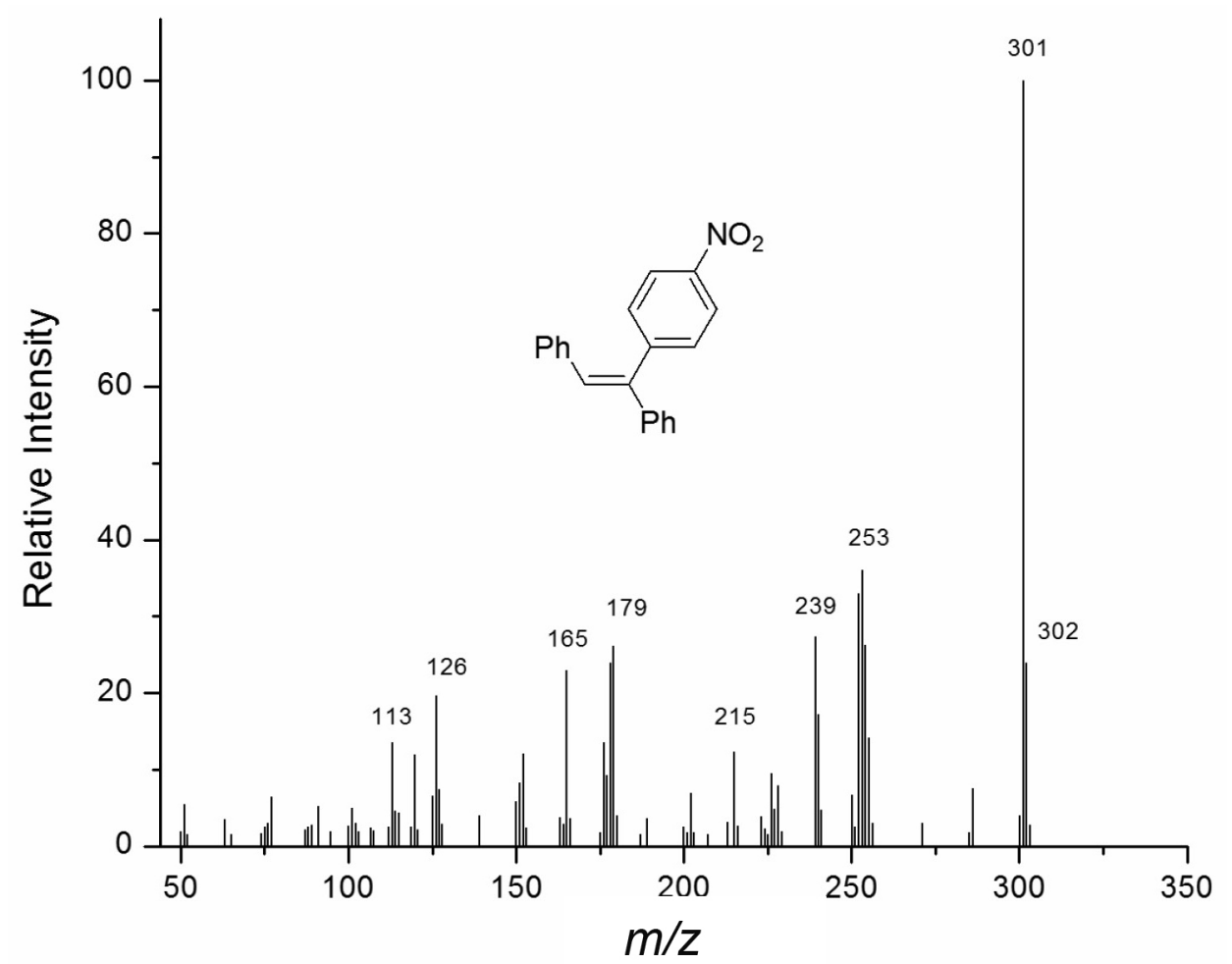

Figure S12. Mass spectrum of 1-((Z)-2-(4-nitrophenyl)-2-phenylvinyl)benzene. 


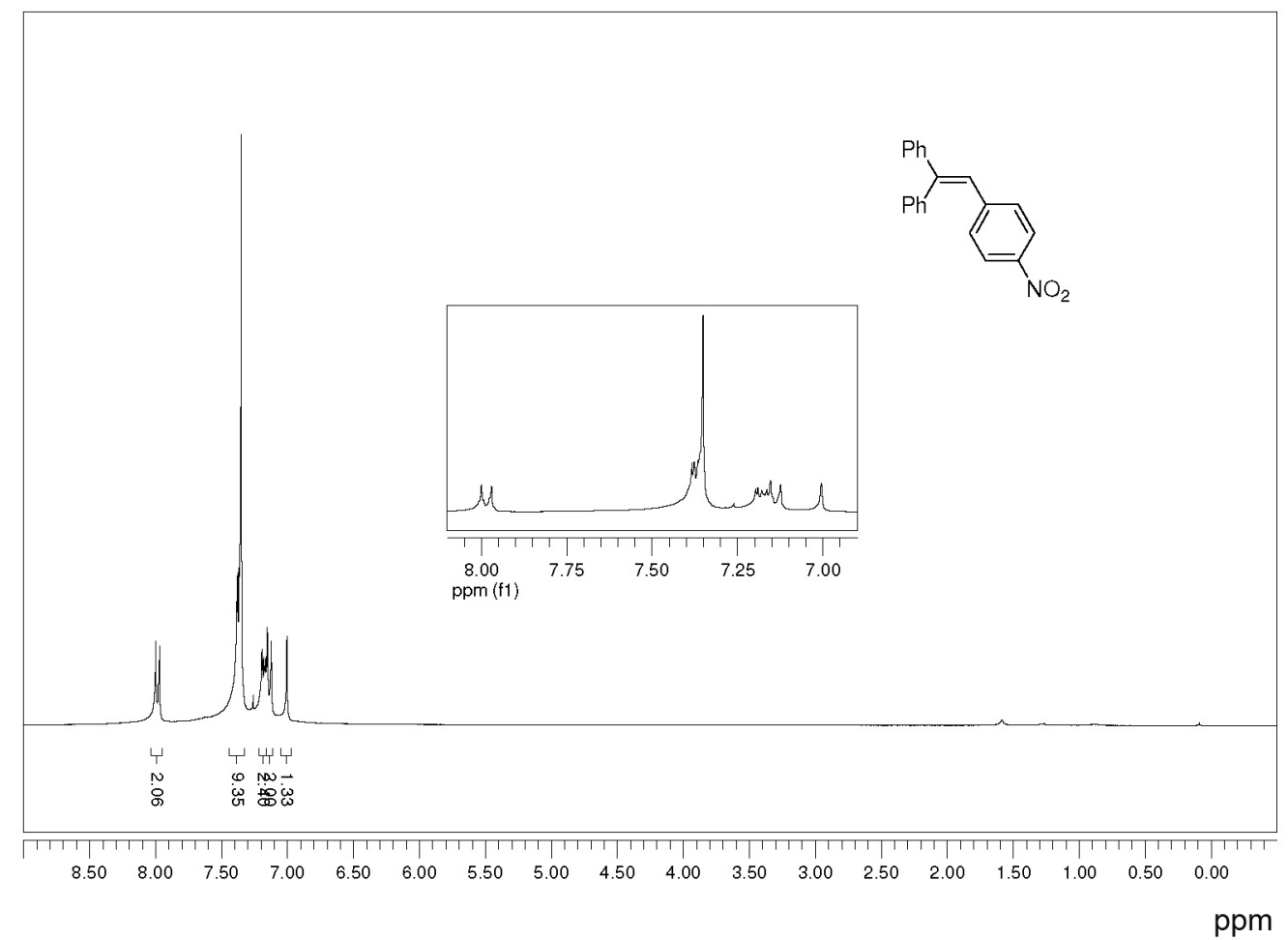

Figure S13. ${ }^{1} \mathrm{H}$ NMR spectrum of 1-(2-(4-nitrophenyl)-1-phenylvinyl)benzene.

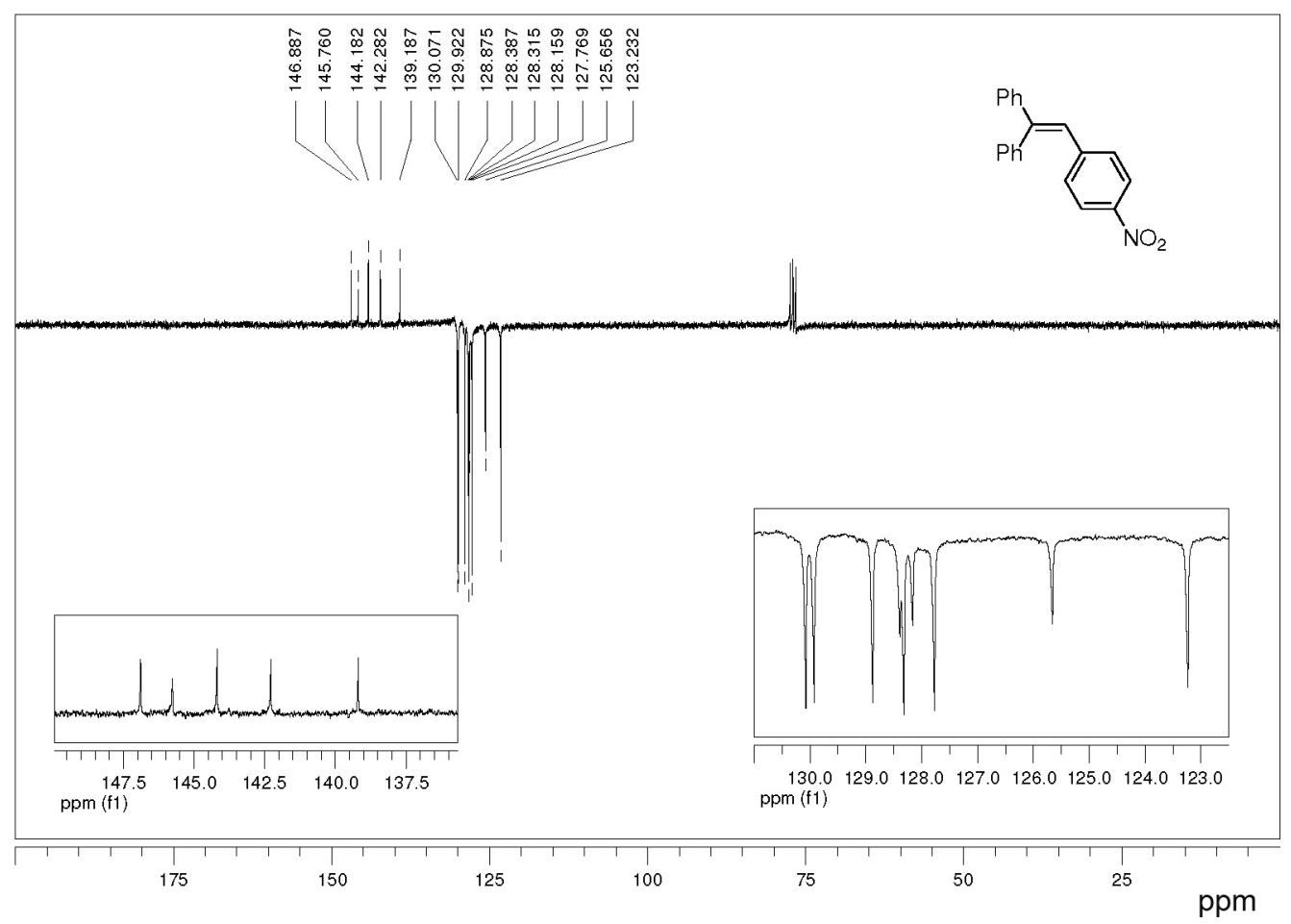

Figure S14. ${ }^{13} \mathrm{C}$ (APT) NMR spectrum of 1-(2-(4-nitrophenyl)-1-phenylvinyl)benzene. 


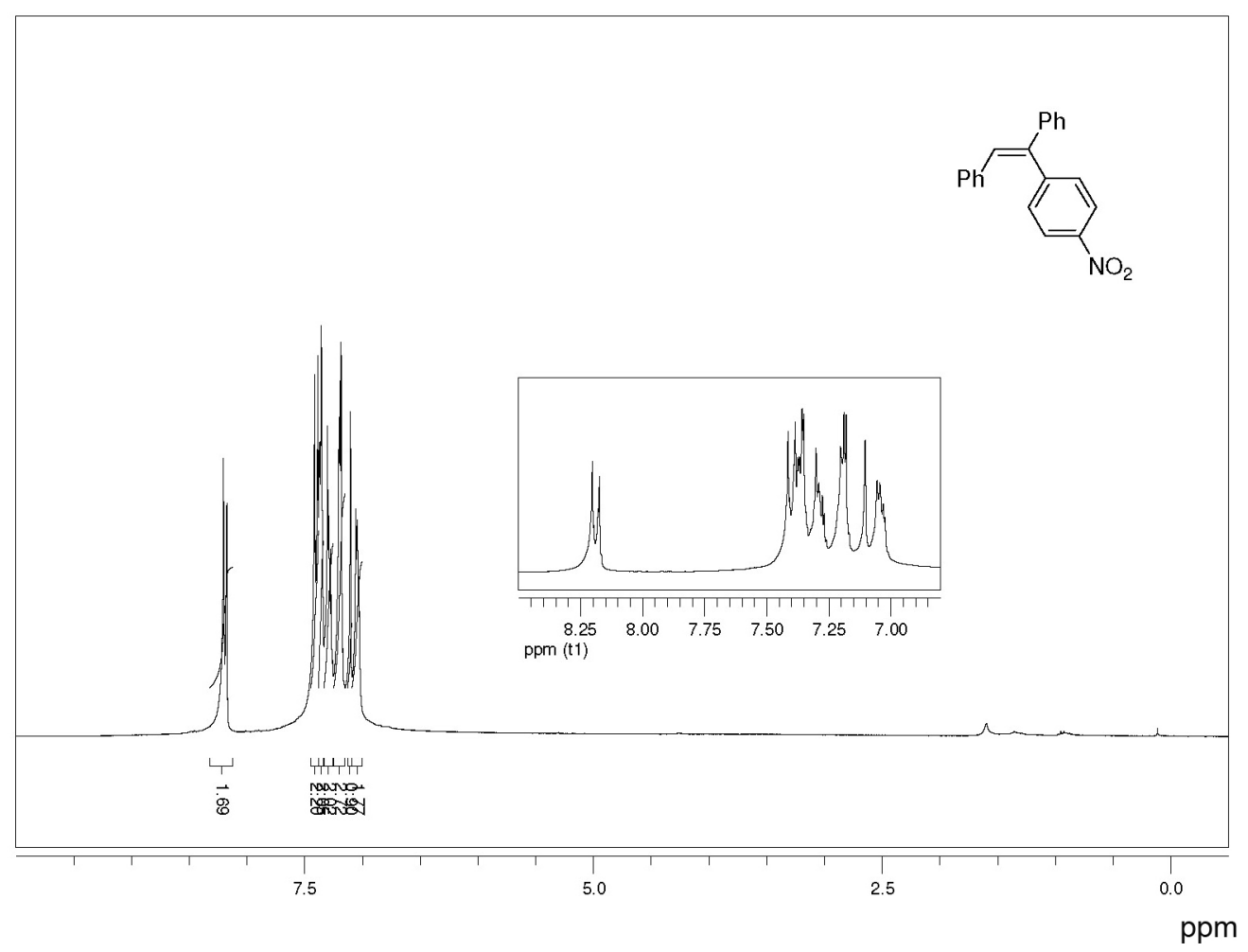

Figure S15. ${ }^{1} \mathrm{H}$ NMR spectrum of 1-((Z)-2-(4-nitrophenyl)-2-phenylvinyl)benzene.

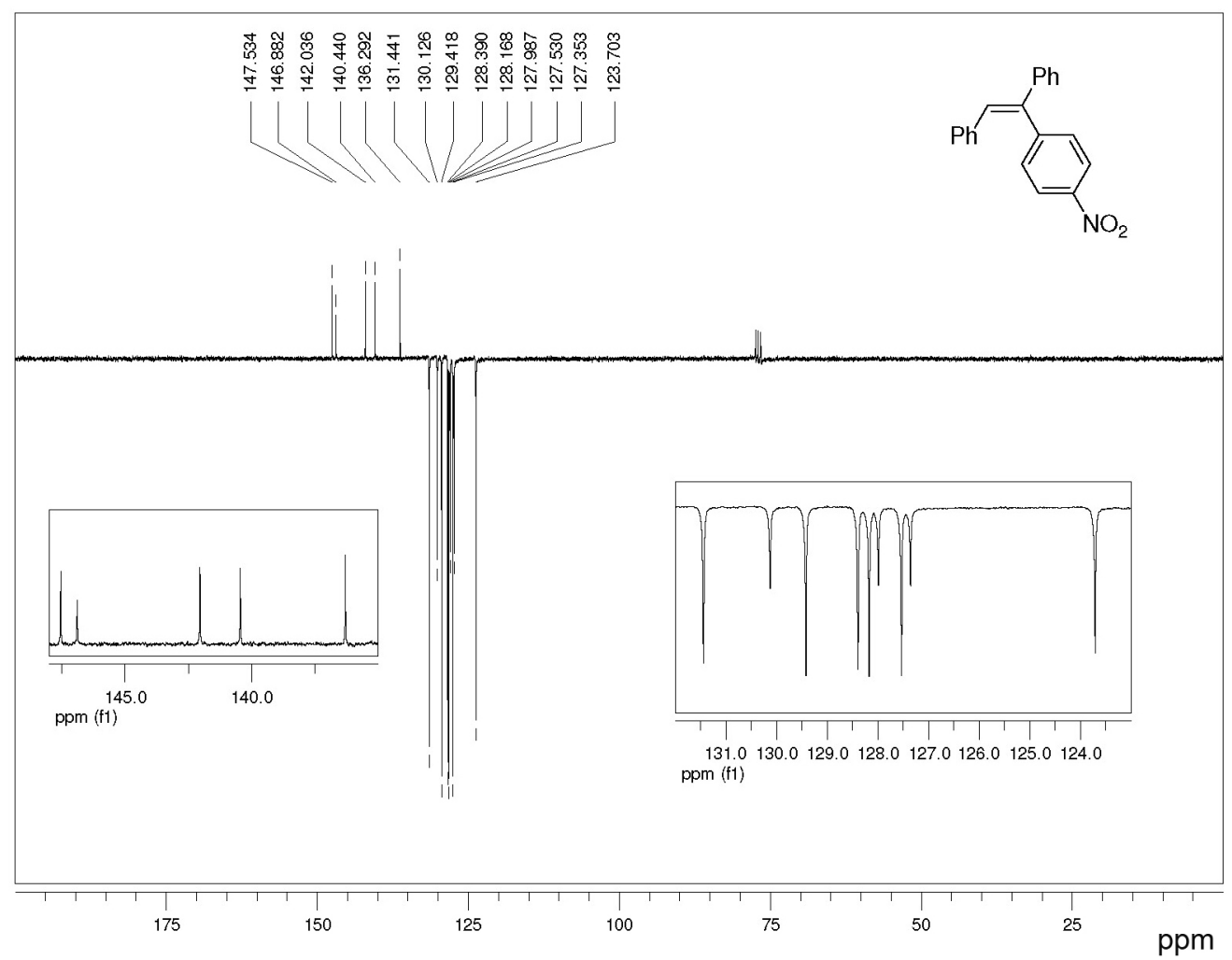

Figure S16. ${ }^{13} \mathrm{C}$ (APT) NMR spectrum of 1-((Z)-2-(4-nitrophenyl)-2-phenylvinyl)benzene. 

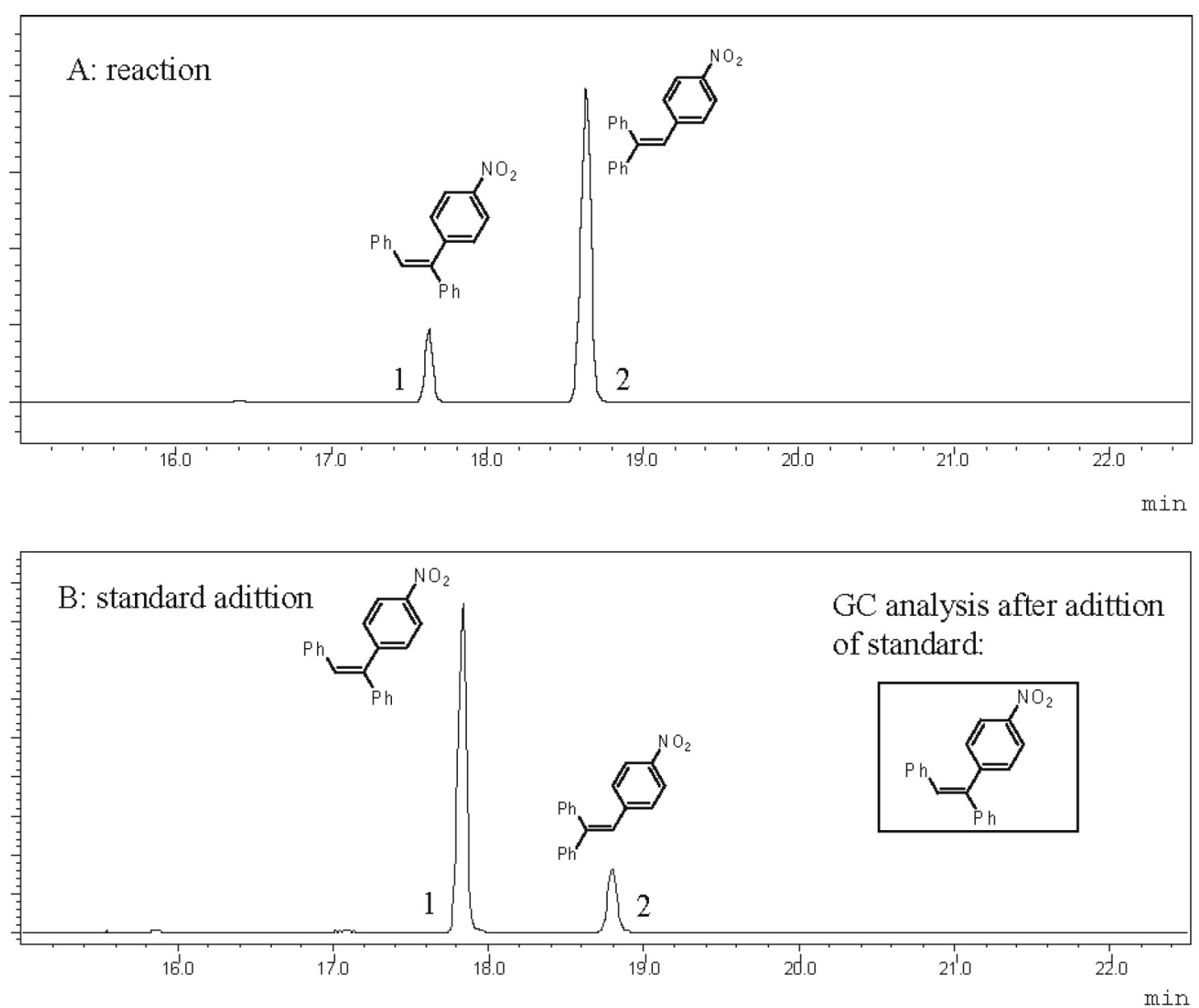

Figure S17. A: GC chromatogram with analysis of Heck reaction between 4-nitro-stilbene and bromobenzene; B: GC analysis of the same sample after addition of 1-((Z)-2-(4-nitrophenyl)-2-phenylvinyl)benzene.

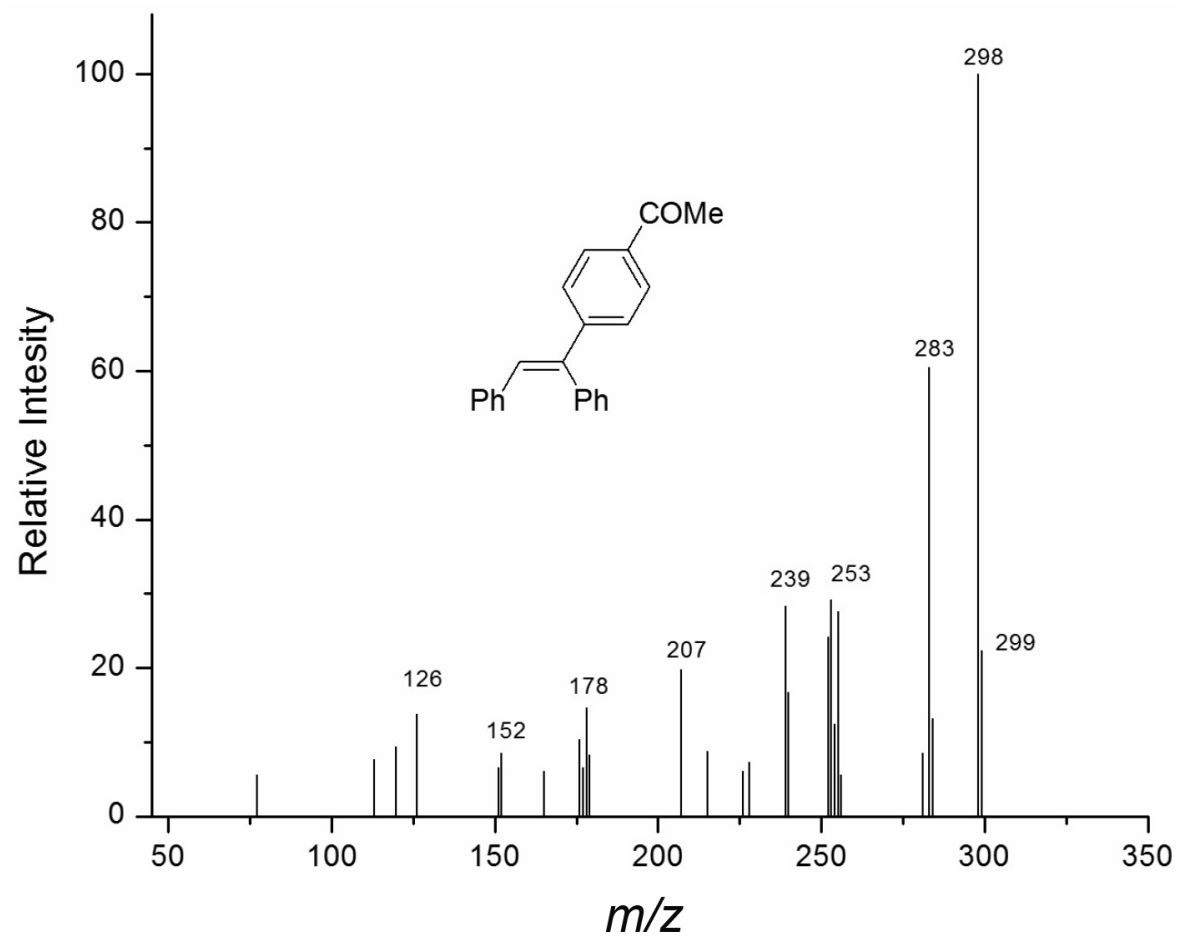

Figure S18. Mass spectrum of 1-(4-((E)-1,2-diphenylvinyl)phenyl)ethanone. 


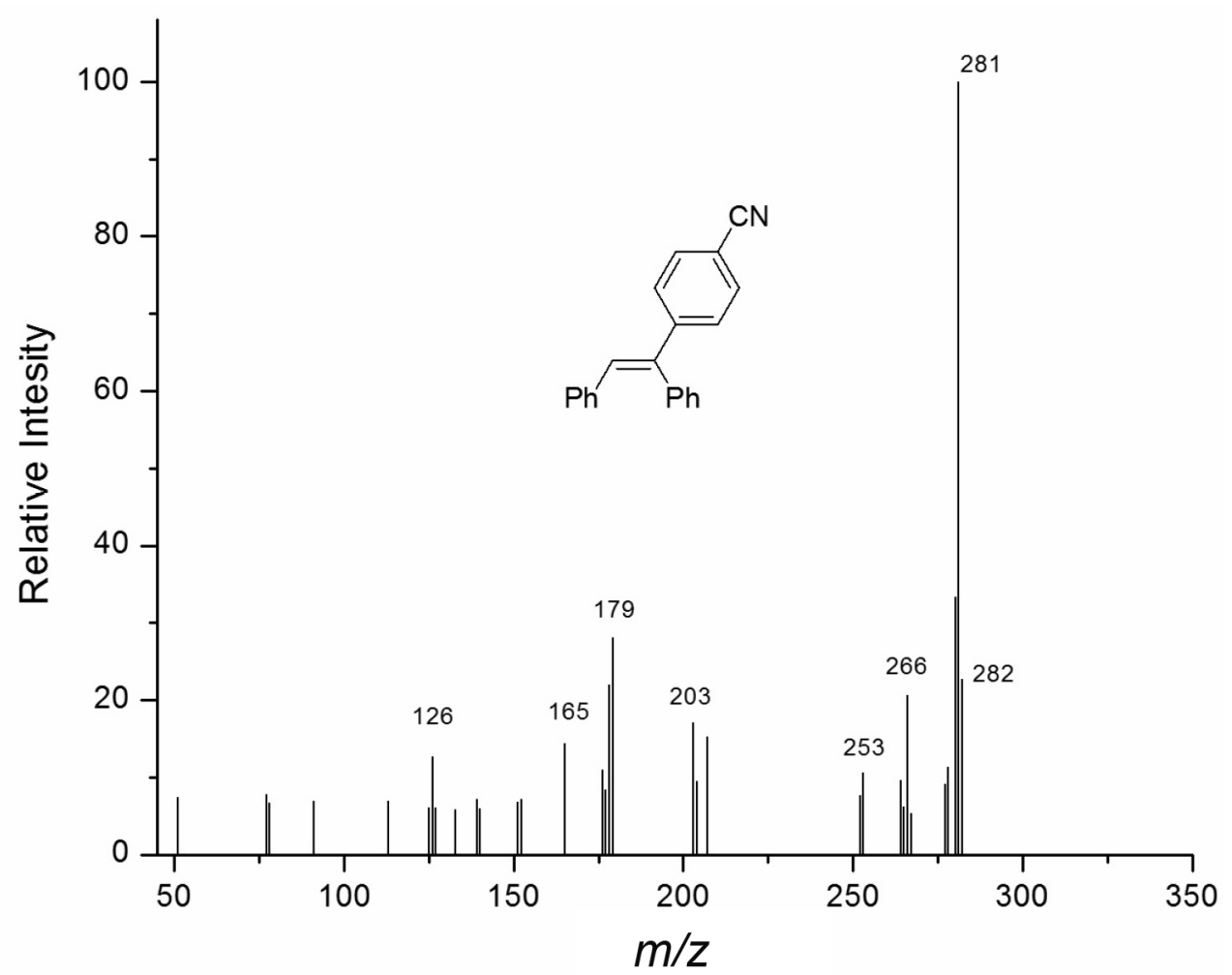

Figure S19. Mass spectrum of 4-((E)-1,2-diphenylvinyl)benzonitrile.

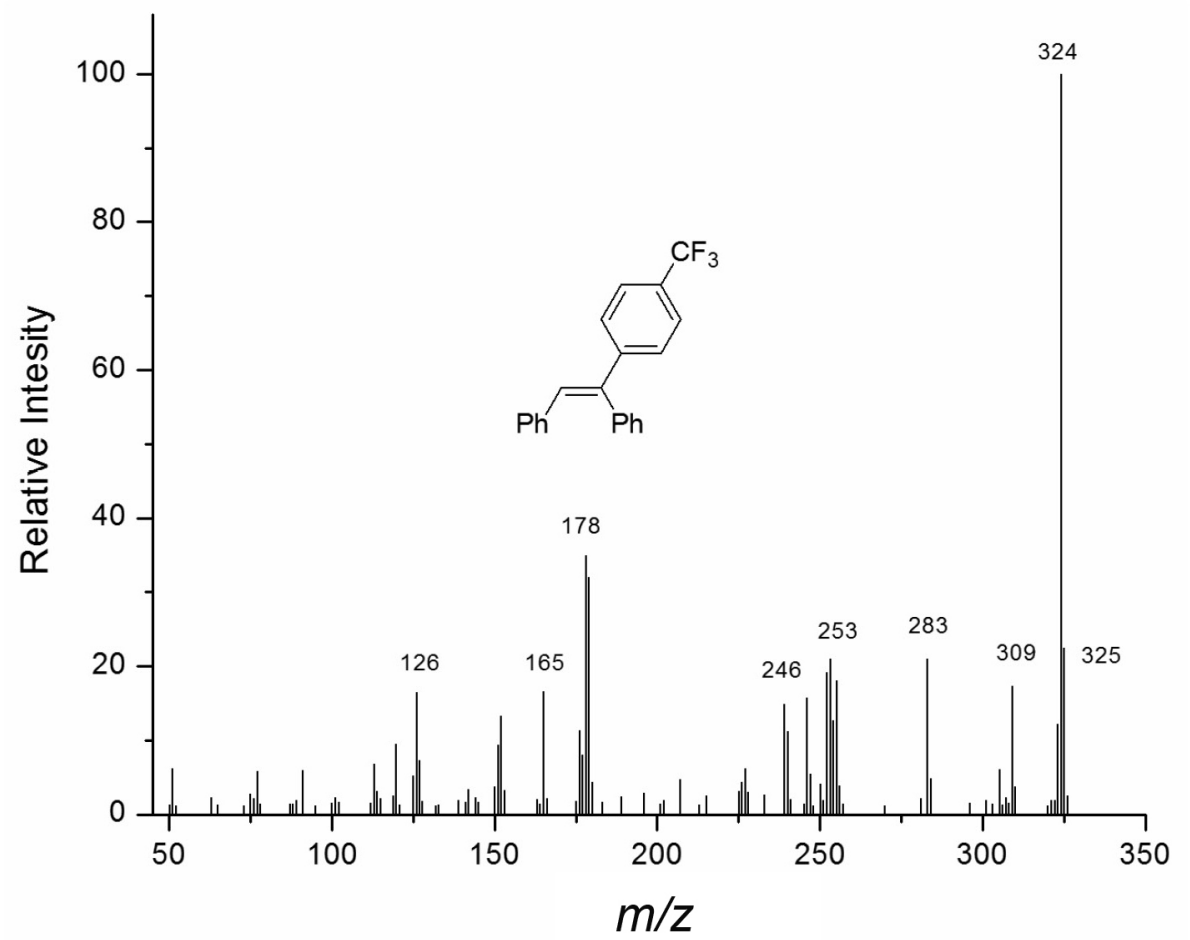

Figure S20. Mass spectrum of 1-(trifluoromethyl)-4-((E)-1,2-diphenylvinyl)benzene. 